Review

\title{
From Waste to Watts: Updates on Key Applications of Microbial Fuel Cells in Wastewater Treatment and Energy Production
}

\author{
Salma Elhenawy ${ }^{1}\left(\mathbb{D}\right.$, Majeda Khraisheh ${ }^{1, *(D)}$, Fares AlMomani ${ }^{1}\left(\mathbb{D}\right.$, Mohammad Al-Ghouti $^{2}(\mathbb{D}$ \\ and Mohammad K. Hassan ${ }^{3}$ (D) \\ 1 Department of Chemical Engineering, College of Engineering, Qatar University, Doha 2713, Qatar; \\ se1105821@student.qu.edu.qa (S.E.); falmomani@qu.edu.qa (F.A.) \\ 2 Environmental Science Program, Department of Biological and Environmental Sciences, College of Arts \\ and Sciences, Qatar University, Doha 2713, Qatar; mohammad.alghouti@qu.edu.qa \\ 3 Center of Advanced Material (CAM), Qatar University, Doha 2713, Qatar; mohamed.hassan@qu.edu.qa \\ * Correspondence: m.khraisheh@qu.edu.qa
}

check for

updates

Citation: Elhenawy, S.; Khraisheh,

M.; AlMomani, F.; Al-Ghouti, M.;

Hassan, M.K. From Waste to Watts:

Updates on Key Applications of

Microbial Fuel Cells in Wastewater

Treatment and Energy Production.

Sustainability 2022, 14, 955. https://

doi.org/10.3390/su14020955

Academic Editor: Andreas

N. Angelakis

Received: 24 November 2021

Accepted: 11 January 2022

Published: 14 January 2022

Publisher's Note: MDPI stays neutral with regard to jurisdictional claims in published maps and institutional affiliations.

Copyright: (c) 2022 by the authors. Licensee MDPI, Basel, Switzerland. This article is an open access article distributed under the terms and conditions of the Creative Commons Attribution (CC BY) license (https:// creativecommons.org/licenses/by/ $4.0 /)$.

\begin{abstract}
Due to fossil fuel depletion and the rapid growth of industry, it is critical to develop environmentally friendly and long-term alternative energy technologies. Microbial fuel cells (MFCs) are a powerful platform for extracting energy from various sources and converting it to electricity. As no intermediate steps are required to harness the electricity from the organic substrate's stored chemical energy, MFC technology offers a sustainable alternative source of energy production. The generation of electricity from the organic substances contained in waste using MFC technology could provide a cost-effective solution to the issue of environmental pollution and energy shortages in the near future. Thus, technical advancements in bioelectricity production from wastewater are becoming commercially viable. Due to practical limitations, and although promising prospects have been reported in recent investigations, MFCs are incapable of upscaling and of high-energy production. In this review paper, intensive research has been conducted on MFCs' applications in the treatment of wastewater. Several types of waste have been extensively studied, including municipal or domestic waste, industrial waste, brewery wastewater, and urine waste. Furthermore, the applications of MFCs in the removal of nutrients (nitrogen and sulphates) and precious metals from wastewater were also intensively reviewed. As a result, the efficacy of various MFCs in achieving sustainable power generation from wastewater has been critically addressed in this study.
\end{abstract}

Keywords: microbial fuel cells; energy production; wastewater treatment; bioelectricity; waste-to-fuel

\section{Introduction}

The increase in world energy demands urged researchers and engineers to overuse fossil fuels, specifically in the oil and gas industry [1-10]. These industries emit greenhouse gases into the atmosphere and their effluents are harmful pollutants to the marine environment [11-13] causing global warming and water pollution. Hence, an alternative greener and more environmentally friendly pathway as an energy source has become a must for decreasing the negative impacts of global warming and water pollution on our planet Earth. Renewable bioenergy is considered one of these alternative pathways to a greener environment [14-16]. Immense efforts are being devoted to research so as to develop biotechnologies that produce bioenergy. The most desirable pathway is to generate energy from renewable resources with a very low carbon footprint [17]. Finding a holistic approach to meeting ever-increasing energy demands in a sustainable manner has piqued the interest of both the research community and industry.

Many sources of waste, such as municipal solid waste, have been investigated and used for energy production. Waste-to-energy approaches and strategies were highlighted as a means for green energy production. Microbial fuel cells (MFCs), which use a direct conversion of waste over anodophilic microorganisms, are gaining significant potential as 
a means of bioelectricity production among waste-to-energy approaches [9]. In this process, a number of waste sources could be utilized, including plant, food, and animal wastes, in addition to sewage sludge, domestic, and other wastes. A large body of published work has demonstrated the potential of using MFCs for bioelectrification production [5-9]. Figure 1 demonstrates the citations count for several publishers about the topic of MFC applications in wastewater treatment. It is clearly seen from Figure 1 that Elsevier holds the largest number of citations (106,864 citations), followed by MDPI, with 33,299 citations, within the years 2017 to 2020 . In this review, we focus on wastewater as a source of green, sustainable bioelectricity production.

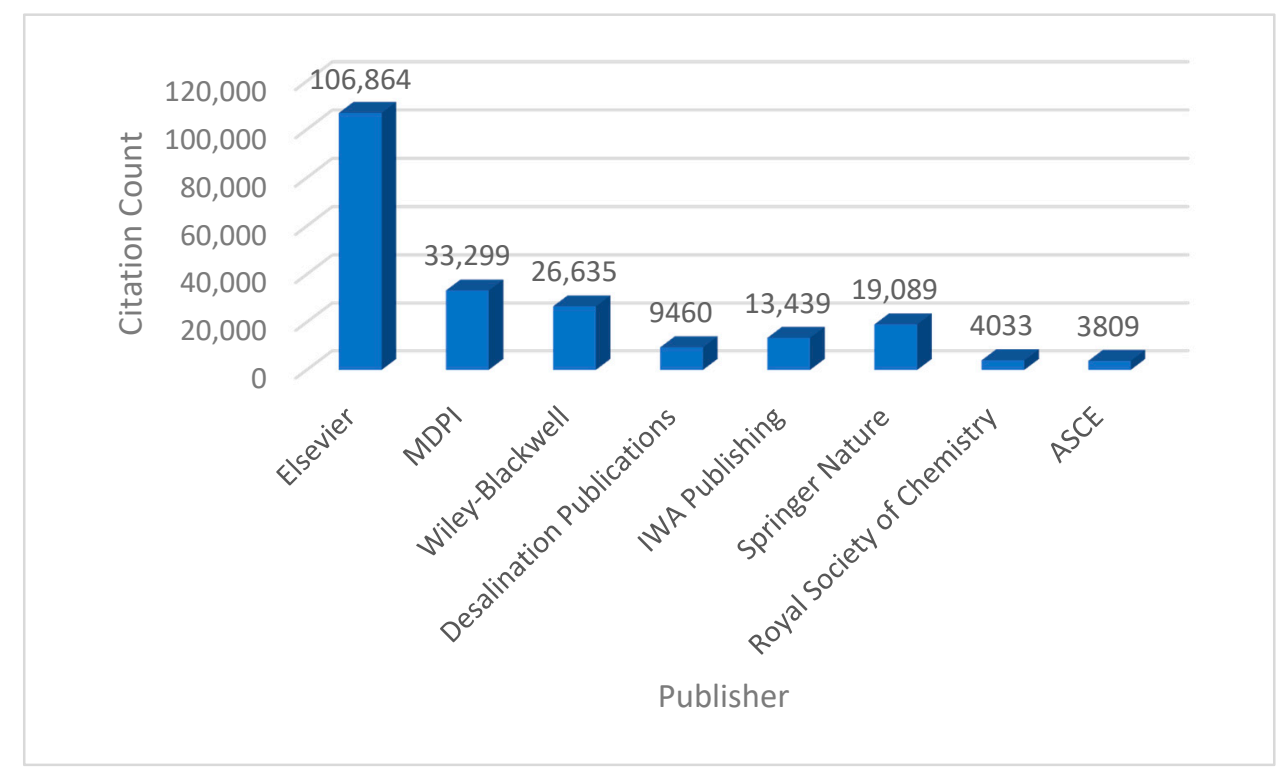

Figure 1. Citations count of MFC applications in wastewater treatment for several publishers from the year 2017 to the year 2020 (Source: Scopus).

By focusing on wastewater treatment, biotechnology is in continuous development for greener ecosystems [18-20], pollutants removal [21-28], and the production of biodegradable materials that provide a new pathway for a better wellbeing [29,30]. Wastewater is currently considered a crucial resource for recycling water [31-36] and saving energy [37-43]. The main types of wastewater include the following: industrial, storm water runoff, and domestic. Each type of wastewater has its own characteristics.

Several technologies have been proposed for the treatment of wastewater, including classical activated sludge treatment and anaerobic digestion. Such technologies have been hindered by high costs and high energy requirements, related to the cost of aeration for effective microbial growth. In addition, wastewater treatments are associated with high greenhouse gas (GHG) emissions, such as $\mathrm{CO}_{2}$ and methane. Typically, the production of 1000 tons of waste is associated with the production of 1500 tons for each $\mathrm{kWh}$ of electricity produced [20]. Although biogas can be effectively produced from anaerobic treatment of wastewater, an additional separation and clean-up process is required, which adds to the energy requirements. Accordingly, current wastewater-to-energy production is deemed energy inefficient and alternative approaches are required [20]. One of the best technologies used for continuous wastewater treatment and saving energy is microbial fuel cells (MFCs). The use of MFCs in wastewater treatment has been extensively studied for the removal and recovery of harmful pollutants and contaminants, such as heavy metals, ammonia $\left(\mathrm{NH}_{3}\right)$, and chemical oxygen demand (COD), via organic matter biological degradation for the generation of electrical energy [44]. Figure 2 shows a timeline of the number of publications on MFCs in wastewater treatment. It is clearly seen from Figure 2 that the publication number increases over time. This shows a great interest in the applications of MFCs in wastewater treatment. Furthermore, the year with the greatest number of publications 
is 2021, with 23,600 publications on MFCs in wastewater treatment. Conversely, the year with the least number of publications is 2010, with 4950 publications on MFCs in wastewater treatment.

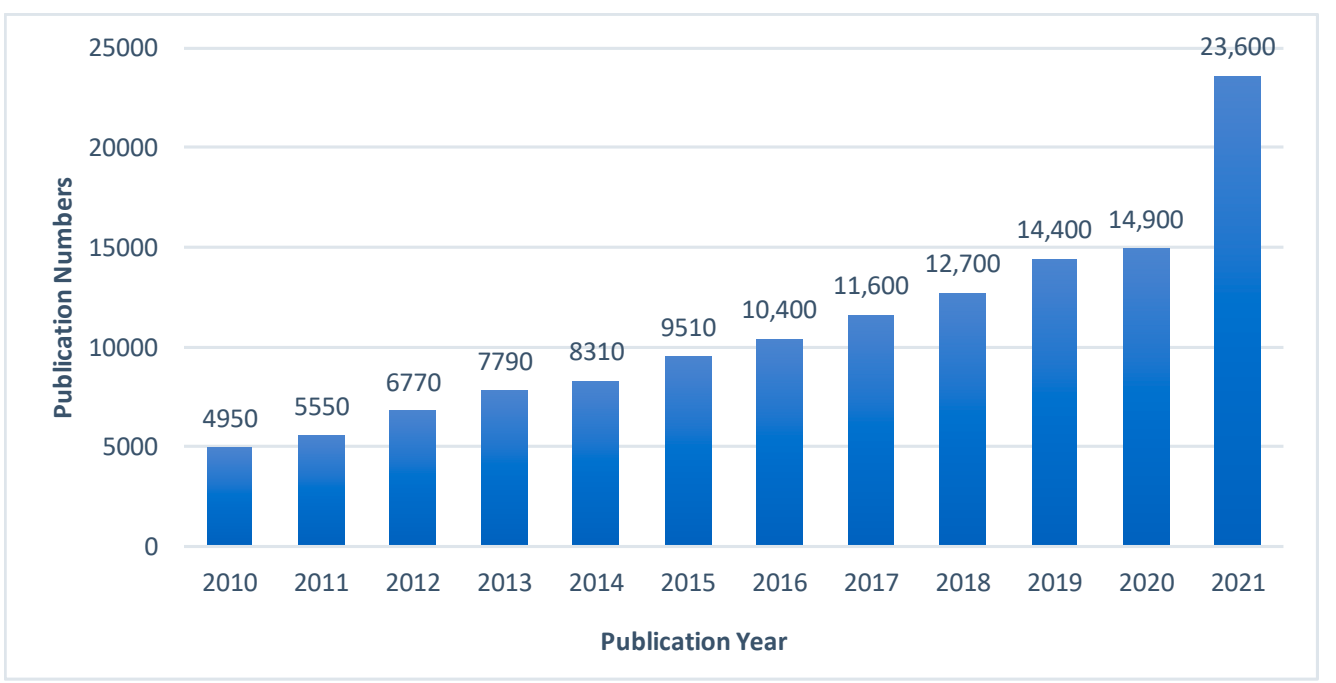

Figure 2. A short, post-2010 MFC timeline representing the number of MFC applications in wastewater treatment-related academic publications (Source: Google Scholar).

Microbial fuel cells (MFCs) combine electrochemical reaction pathways with microbial metabolisms [20] and convert organic energy to electrical energy directly [45], thus decreasing waste and producing electric energy. When compared to other wastewater treatment methods, MFC technology is a type of bioelectrochemical system (BES) that has recently gained popularity due to its low cost and low level of negative environmental impacts, such as sludge formation and greenhouse gas emissions [46-48]. In addition, MFCs are associated with energy production, heavy metal removal, and bio-removal of toxic waste.

MFCs, a bio-electrochemical, system typically consist of two sections: an anode and cathode chambers. In the anode chamber is the main "powerhouse" of the system, where the microorganisms are used as biocatalysts to oxidize the organic substrate.

Microorganisms hold a crucial part in these technologies, since they form electron-rich metabolites, produce redox mediators, preserve a redox gradient, and transport electrons to an electrode via direct electron transfer or through a soluble electron transfer mediator, while producing electricity as the main product [49]. Many factors affect the efficiency of the system, such as the chamber design and system operational conditions.

With this backdrop, the use of MFCs in wastewater treatments shows potential as a candidate for green sustainable wastewater treatment and energy generation. Having said that, this technology has not yet been fully realized as a practical effective alternative to current wastewater treatment technologies. This short overview focuses on highlighting the applications of MFCs in the treatment of wastewater using several types of wastewater, including municipal or domestic wastewater, industrial wastewater, brewery wastewater, and urine wastewater. In addition, this review emphasizes the application of MFCs for the removal of nutrients and precious metals from wastewater.

\section{Historical Evolution of Microbial Fuel Cells (MFCs)}

Generally speaking, almost all types of microbes can be successfully applied as biocatalysts in an MFC. The first MFC idea was introduced by Potter in the year 1910, in which Saccharomyces bacteria and Escherichia coli bacteria were used to produce electrical energy while using platinum electrodes [50]. This concept did not catch the interest of researchers until the 1980s, when it was found that the addition of electron mediators enhanced the power output and current density. The outer layers of most microbial organisms are made up of non-conductive lipid membranes, lipopolysaccharides, and peptidoglycans, which 
slow down direct electron transfer to the anode. As a result, the addition of electron mediators accelerates electron transfer from the cathode to the anode [51]. There are several synthetic exogenous mediators, including metalorganics, and dyes, including methylene blue (MB) [52], methyl orange [53], neutral red (NR) [53], thionine [54], and potassium ferricyanide [55]. However, the use of synthetic mediators in MFCs is hampered by their instability and toxicity [56]. Fortunately, a wide range of microbes, including microbial metabolites (endogenous mediators), may use naturally occurring compounds as mediators [57]. Anthraquinone and humic acids have the ability to pass electrons from the cell membrane to the anode [58]. When microbes were discovered to pass electrons directly to the anode in 1999, it was a major breakthrough [59]. These microbes have a high Coulombic efficiency and are stable in operation [60]. Unfortunately, the mediators have a high cost. Thus, MFCs that do not require a mediator are preferably used in wastewater treatment. Figure 3, below, shows the historical development of MFC technology. The following potential benefits make MFC applications appealing in general [60,61]: (1) energy from the substrate is converted directly into electricity; (2) no additional biogas treatments are required when compared to anaerobic digestion (AD); (3) the conversion of organics to energy is quite efficient; (4) there is little excess activated sludge produced, and (5) there is little reliance on external influences. Despite their benefits, MFCs face challenges in terms of the production of power density, costs, and long-term stability. Hence, the integration of MFCs with other technologies appears to mitigate these downfalls and accelerate MFC growth and commercialization in the wastewater treatment industry [49].

\section{Historical evolution of MFC}

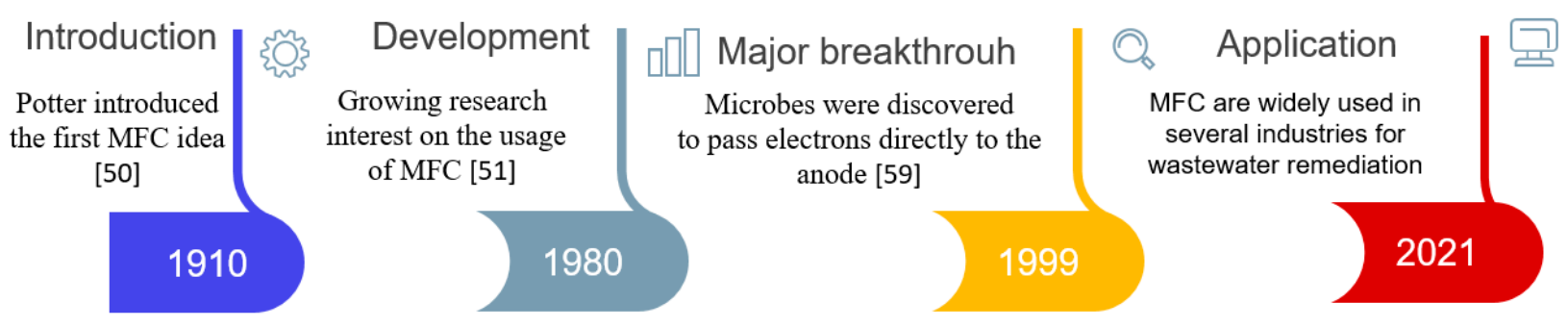

Figure 3. Historical evolution of MFCs, [50,51,59].

\section{Microorganisms Applied in Microbial Fuel Cells}

In addition to the physical design of the MFC system, the biocatalyst inoculation is an essential factor that will affect the generation of the bioelectricity in the system.

Several types of microorganisms are capable of transferring electrons produced by organic matter metabolism to the anode. As such, exoelectrogens generate electricity via the oxidation of the organic compounds available in the substrate. These microorganisms, as well as their substrates, are demonstrated in Table 1 below. Marine and freshwater sediment, soil, wastewater, and activated sludge are all rich in these microorganisms [61,62]. Several recent studies have focused on microbe screening and identification, as well as the enhancement of a chromosomal library for microorganisms that can produce electricity via the degradation of organic matter [63,64]. The technique behind the anodic electron transfer in MFCs is crucial to grasp the principle behind how they operate [65]. 
Table 1. Several microorganisms used in MFCs, with their mediators.

\begin{tabular}{|c|c|c|c|}
\hline Microorganism & Substrate & Mediators & Reference \\
\hline Proteus mirabilis & Glucose & Thionine & [66] \\
\hline Saccharomyces cerevisiae & Hydrolyzed Lactose & Neutral red (NR), Methylene blue (MB) & [67] \\
\hline Escherichia coli & Glucose & Neutral red (NR) & {$[68]$} \\
\hline Rhodoferax ferrireducens & Glucose & Without mediator & [69] \\
\hline Enterobacter cloacae & Glucose & Methyl Viologen, Methylene blue (MB) & [70] \\
\hline Saccharomyces cerevisiae & Glucose & Resorufin & [71] \\
\hline Enterococcus faecium & Glucose & Pyocyanin & [72] \\
\hline Aeromonas hydrophila & Glucose, Acetate & Without mediator & [73] \\
\hline Shewanella putrefaciens & Lactate & Without mediator & [74] \\
\hline Geobacter sulfurreducens & Acetate & Without mediator & {$[75]$} \\
\hline Streptococcus lactis & Glucose & Ferric Chelate complex & [76] \\
\hline Activated sludge & Wastewater & Without mediator & [77] \\
\hline Proteus vulgaris & Glucose, Maltose, Galactose & Thionin & [78] \\
\hline Domestic wastewater & Glucose, Xylose & Humic acid & [79] \\
\hline Gluconobacter oxydans & Glucose & $\begin{array}{l}\text { 2-hydroxy-1,4-naphthoquinone (HNQ), } \\
\text { Resazurin, Thionine }\end{array}$ & [78] \\
\hline Klebsiella pneumoniae & Glucose & 2-hydroxy-1,4-naphthoquinone (HNQ) & [80] \\
\hline Shewanella oneidensis & Lactate & Anthraquinone-2,6-disulfonate (AQDS) & [81] \\
\hline Shewanella putrefaciens & Lactate, Pyruvate, Acetate & Neutral red (NR) & [65] \\
\hline Actinobacillus succinogenes & Glucose & Neutral red (NR), Thionine & {$[82]$} \\
\hline Mixed consortium & Glucose, Sucrose & Without mediator & [83] \\
\hline Micrococcus luteus & Glucose & Thionine & [84] \\
\hline
\end{tabular}

Typically, the microbial cell membranes, consisting of materials such as polysaccharides and essential lipids, are non-conductive. The anode chamber contains the microorganisms (catalyst) and the anode electrode. It is typical to feed this chamber with the organic substrate of wastewater in addition to a redox mediator (unless it is a mediator-less MFC system) (Figure 4). Accordingly, the MFC system may be classified based on the external mediator requirements. The two most-known types are the mediator and mediator-less MFCs. In the first type, a syntactic mediator (chemical) is added to mediate the electron transfer from the microorganism to the anode. In an indirect MFC and a mediator MFC (Figure 4A,B, respectively), fermentative microorganisms require the addition of artificial mediators that can shuttle the electrons between the cell membrane and the anode. Figure $4 \mathrm{~B}$ shows the required redox couple (oxidation-reduction) of the e-mediator. In this type, the mediator is required, as the used microorganisms in the MFC are unable to donate the electrons in a direct fashion due to the nonconductive cell surface. Many types of mediators are used, including benzylviologen, phenothiazine and others [20]. Microorganisms such as enterococcus and pseudomonas, for example, may generate their own electrode shuttles and, accordingly, facilitate the electron transfer (Figure 4A). Bacteria were reported to produce natural mediators under some stressed conditions (Figure 4B) [20]. Direct transportation of electrons in MFCs is considered one of the most important mechanisms for electron transfer (Figure 4C). Here, the electrons are typically generated during the respiration of electroactive bacteria to the anode. 

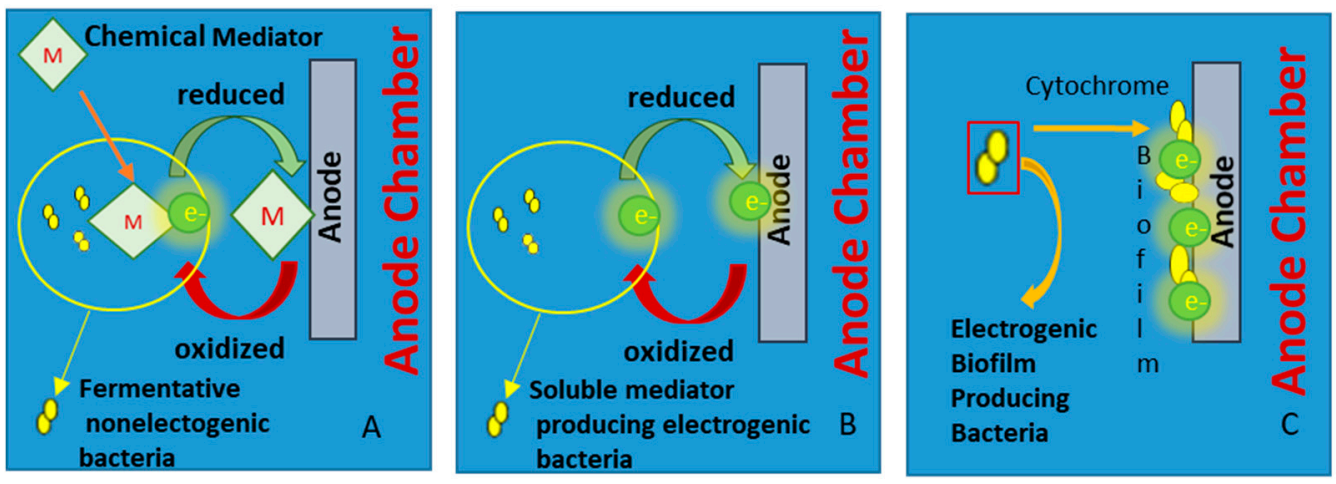

Figure 4. MFC electron transfer mechanisms: (A) indirect MFC; (B) mediator MFC; (C) mediatorless MFC.

When a MFC is inoculated with anaerobic sludge or marine sediments, mixed cultured microbes are present in the anode chamber. MFCs with mixed cultures have great performance most of the time. The use of complex mixed cultures allows for a much broader substrate usage. The bacteria in the MFC system can utilize a number of substrates, such as wastewaters with biodegradable organic matter that is utilized as the main energy source.

\section{Features of MFCs and Operating Mechanisms}

As can be seen in Figure 5, MFCs typically consist of an aerobic cathodic chamber and an anaerobic anodic chamber. Each is separated by a proton exchange membrane or an ion exchange membrane (PEM), as can be seen in Figure 5. The electrogenic bacteria's redox reaction generates bioelectricity.

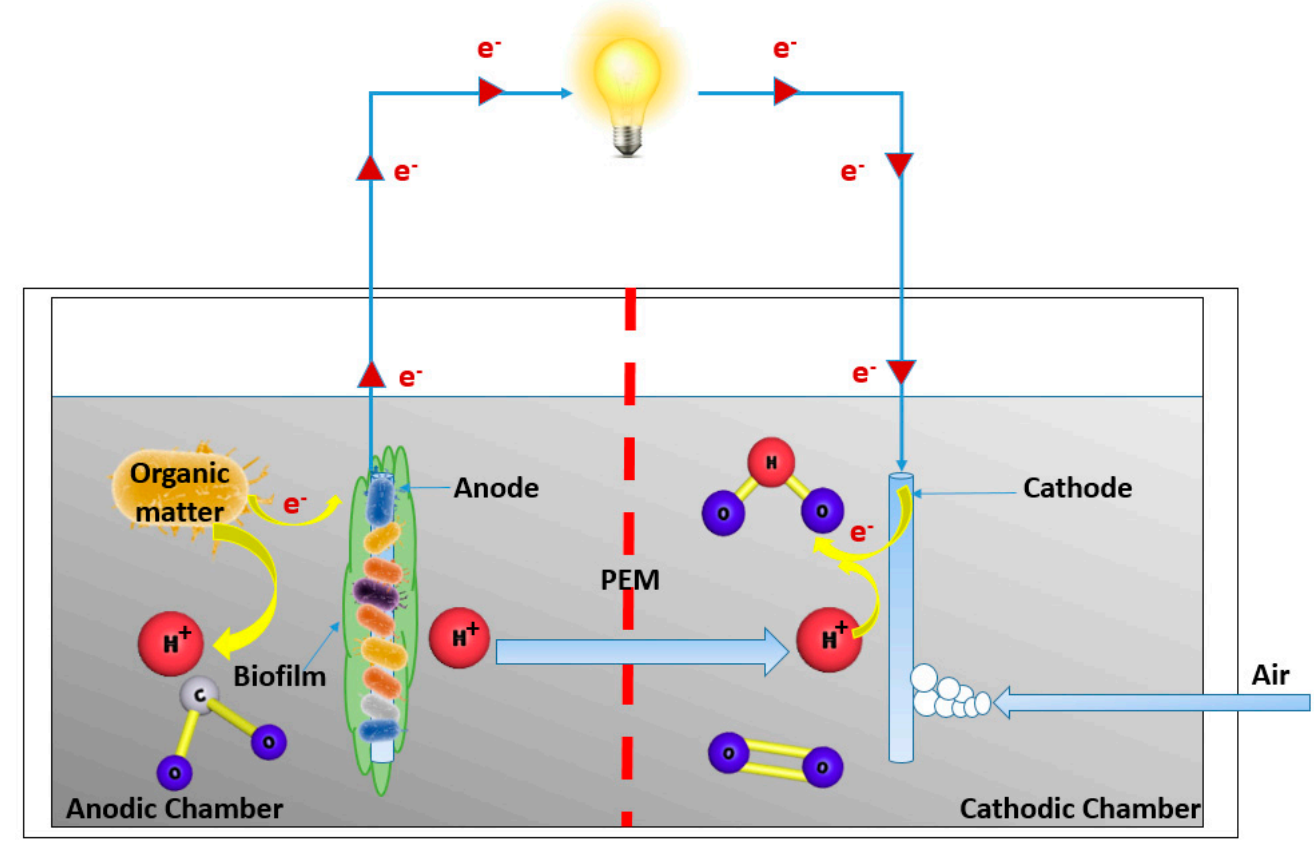

Figure 5. Schematic diagram of a microbial fuel cell (MFC).

The proton exchange membrane is a selective membrane that allows protons to diffuse from the anode to the cathode and that prohibits the diffusion of oxygen to the anode chamber $[85,86]$. The organic compounds, including carbohydrates found in wastewater, are oxidized in an anodic chamber as electron donors via active microorganisms, resulting in the production of electrons and protons. After that, the electrons are moved to the anode, then to the cathode in the cathodic chamber, where they produce electricity [87]. The 
protons then diffuse into the PEM and to the cathode chamber, where an electron acceptor, electrons, and protons combine to produce water.

The proton exchange membrane is a selective membrane that allows protons to diffuse from the anode to the cathode and that prohibits the diffusion of oxygen into the anode chamber $[85,86]$. The organic compounds, including carbohydrates found in waste, are oxidized in an anodic chamber as electron donors by active microorganisms, resulting in the production of electrons and protons. After that, the electrons are moved to the anode and then to the cathode in the cathodic chamber, where they produce electricity [87]. The protons then diffuse into the PEM and into the cathode chamber, where an electron acceptor, electrons, and protons combine to produce water. Table 2 shows the typical components of a microbial fuel cell (MFC). Any available organic substrate is degraded into $\mathrm{CO}_{2}$ as a result of microbial activity and cell respiration. In the microbial degradation process, protons and electrons are generated in the anode compartments. The electrons produced in this chamber migrate to the cathode compartment, producing electricity as a result of the potential difference that is created. In addition, terminal electron acceptors $\left(\mathrm{O}_{2}\right)$ are reduced to form water in the cathode chamber. Oxygen is typically available in abundance in the system and is considered an effective electron acceptor. Some other electron acceptors, such as hydrogen peroxide, can also be utilized in the chamber. Equations (1) and (2), below, demonstrate the reactions that occur at the electrodes [88]. Conversely, the proton transfer through the semi-permanent PEM is from the anode to the cathode chambers and combines with the $\mathrm{O}_{2}$ and electrons present in the wastewater molecules. Anaerobic conditions favor effective bioelectricity production as such an environment is needed for the growth of microorganisms, such as G. sulfurreducens.

Table 2. Typical components of a microbial fuel cell.

\begin{tabular}{ccc}
\hline Component & Materials & Requirement \\
\hline Anodic chamber & Glass, Plexiglas, polycarbonate & Required \\
\hline Cathodic chamber & Glass, Plexiglas, polycarbonate & Not required \\
\hline Cathode & Graphite, carbon paper, graphite felt, Pt & Required \\
\hline Anode & $\begin{array}{c}\text { Graphite, carbon paper, Pt, reticulated } \\
\text { vitreous carbon (RVC) }\end{array}$ & Required \\
\hline Electrode catalyst & Pt, MnO2, polyaniline, Fe & Not required \\
\hline Proton exchange system & Proton exchange membrane (PEM): & Required \\
\hline
\end{tabular}

In effective designs, it is essential to separate the chambers to ensure that full anaerobic conditions are maintained in the anodic section. The PEM plays an essential role in separating the two chambers, having specific selectivity for certain protons, maintaining high conductivity, and having high mechanical strength and durability for the long operation of the system. As shown in Figure 5, the PEM membrane separates the anode and cathode chambers in a typical MFC system. As indicated earlier, the PEM plays a fundamental role in power production in the cell as it controls the movement of protons from the anode compartment to the cathode one. The movement can be affected by the concentration polarization effect on the PEM membrane and can cause reduced power generation in the system. Another function of the PEM is the control of the substrate flux and $\mathrm{O}_{2}$ diffusion towards the anode chamber.

I. Anodic reaction

$$
\left(\mathrm{CH}_{2} \mathrm{O}\right)_{\mathrm{n}}+\mathrm{nH}_{2} \mathrm{O} \rightarrow \mathrm{nCO}_{2}+4 \mathrm{ne}^{-}+4 \mathrm{nH}^{+}
$$

II. Cathodic reaction

$$
\mathrm{O}_{2}+4 \mathrm{ne}^{-}+4 \mathrm{nH}^{+} \rightarrow 2 \mathrm{H}_{2} \mathrm{O}
$$


In the anode chamber, the substrate is filled with exoelectrogen bacteria that grow and oxidize the organic substrates, transferring the produced electrons to the electron accepters found outside their cells. In addition, protons can be produced but are moved from the anode to the cathode compartments using deferential potential through the PEM. This is in contrast to the movement of electrons, as they require an external circuit [20].

Enhanced cell and electrode design, system optimization, and the addition of mediators could enhance the electron transfer and the system's effectiveness.

Anode materials are selected in such a way to ensure the establishment of a favorable environment for the development of active biofilms. Carbon-based materials such as cloth and different fibrous materials are utilized as anode materials especially if exoelectrogens are used in the MFC system. Other polymer-based materials such as polytetrafluoroethylene are preferred. Carbon nanotubes were also reported as means to feasibly transfer the electrons and enhance the surface area of the anode [20].

One of the most important parts of the MFC is the cathode material, as it has a main impact on the produced power in the system. Materials with high redox potential are preferred, such as graphite, $\mathrm{Cu}, \mathrm{Pt}$, and most commonly, carbon paper. The use of $\mathrm{Pt}$ in the cathode compartment has been shown to improve MFC system performance by increasing the reaction rate and decreasing the cathode reaction activation energy. The enhancement was reported in the first $24 \mathrm{~h}$ of operation in comparison to non-Pt-based cathode materials. After this time, both Pt-based and non-Pt-based cathode materials performed similarly with respect to power generation from the MFC system. Recent studies have shown that metal carbon nitrogen materials are outperforming Pt-based cathodes with respect to durability and prolonged system operation. Such materials could be easily produced using a variety of transition metals and precursors containing nitrogen and carbon.

\section{Microbial Fuel Cells (MFCs) Applications in Wastewater Treatment}

Microbial fuel cells have attracted great attention in recent decades as a distinguishable sustainable technology for generating energy and treating wastewater. Microbial fuel cells have proven to be a better option for wastewater treatment than conventional technologies because of their higher conversion efficiency and lower solid waste generation. In addition, they are capable of operating at any ambient temperature. Furthermore, by completely removing chemical oxygen demand (COD) and other contaminants, MFCs are fully capable of producing power densities of $4200 \mathrm{~mW} / \mathrm{m}^{3}$ [89-92].

The reactor configuration is a major factor that can affect the performance of the MFC. Designs can consist of single or dual chambers, as described in Figure 6. In the single-chamber design (Figure 6A), the cathode is kept in direct contact with air. The main obvious advantage of this type of design is the simple and less-costly design, as no separate cathode compartment is required. As air is in direct contact with the cathode, no aeration is required either. Separate anode and cathode chambers are required in the dual MFC design (Figure 6B), where both chambers are separated by the membrane. One of the main advantages of this design is the flexibility of the system, as each of the chambers can be operated in a batch or continued mode as required. The decision regarding the use of a single or dual design will depend on many operational and system requirements.

Table 3 shows the performance of various types of MFCs in the treatment of several types of wastewater, proving the efficiency of MFCs in their treatment applications. 


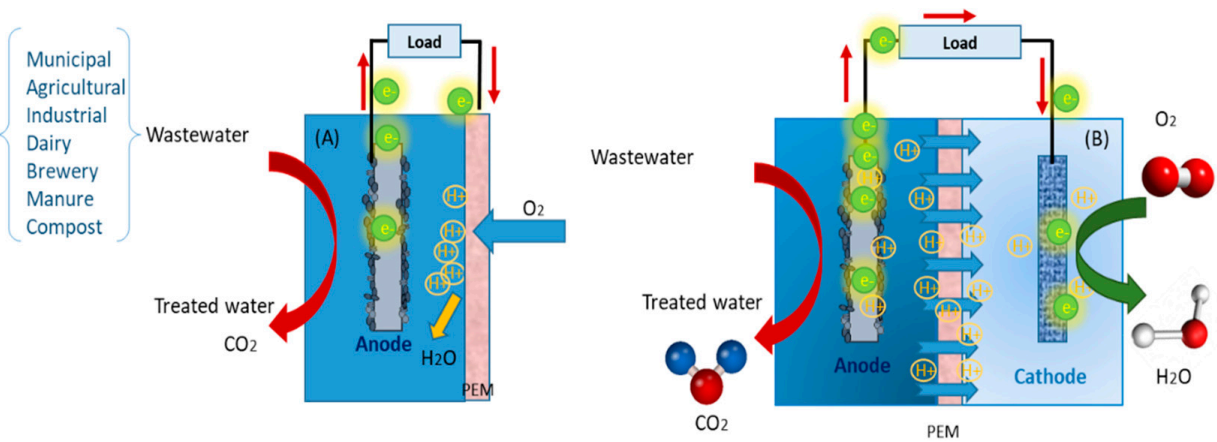

Figure 6. MFC design: (A) single cell and (B) dual cell.

Table 3. Various power outputs from different MFC configurations and wastewater feed.

\begin{tabular}{|c|c|c|c|c|}
\hline MFC Configuration & Wastewater & $\begin{array}{c}\text { COD Removal } \\
(\%)\end{array}$ & Power & References \\
\hline 50 stacked triple chambers & Municipal & 70 & $125 \mathrm{~W} / \mathrm{m}^{3}$ & [93] \\
\hline 4 single & Municipal & 40 & $82 \mathrm{~mW} / \mathrm{m}^{2}$ & [94] \\
\hline Dual & Swine & 83 & $13 \mathrm{~mW} / \mathrm{m}^{2}$ & [95] \\
\hline Dual & Industrial acid mine and municipal & 15 & $1188 \mathrm{~mW} / \mathrm{m}^{2}$ & [96] \\
\hline Up-flow & Retting & 70 & $254 \mathrm{~mW} / \mathrm{m}^{2}$ & [97] \\
\hline Single & Wood hydrothermal & 94 & $178 \mathrm{~mW} / \mathrm{m}^{2}$ & [98] \\
\hline Flat panel & Domestic & 85 & $6.3 \mathrm{~W} / \mathrm{m}^{3}$ & [99] \\
\hline Anaerobic baffled reactor-MFC & Fecal & 93 & $450 \mathrm{mV}$ & [100] \\
\hline Single & Synthetic & 57 & $14.41 \mathrm{~mW} / \mathrm{m}^{2}$ & [101] \\
\hline 3 dual stacked & Biological treatment & 84 & $822 \mathrm{~mW} / \mathrm{m}^{2}$ & [102] \\
\hline Up-flow MBR-MFC & Synthetic & 85 & $44.4 \mathrm{~mW} / \mathrm{m}^{2}$ & [103] \\
\hline MBR-MFC & Synthetic & 87.8 & $2.18 \mathrm{~W} / \mathrm{m}^{3}$ & [104] \\
\hline Single & Petroleum refinery & 47 & $132 \mathrm{~mW} / \mathrm{m}^{2}$ & [105] \\
\hline Dual & Hospital & 60 & $14 \mathrm{~W} / \mathrm{m}^{3}$ & [106] \\
\hline Single & Sludge & 25.8 & $17.8 \mathrm{~W} / \mathrm{m}^{3}$ & [107] \\
\hline MBR-Dual & Paper & 51.3 & $56.1 \mathrm{~mW} / \mathrm{m}^{2}$ & [108] \\
\hline CW-MFC & Azo dye & 85.66 & $61.9 \mathrm{~mW} / \mathrm{m}^{3}$ & [109] \\
\hline 3 chambers & Synthetic & 97 & $111 \mathrm{~mW} / \mathrm{m}^{3}$ & [110] \\
\hline 5 stacked MFCs & Synthetic & 97 & $50.9 \mathrm{~W} / \mathrm{m}^{3}$ & [111] \\
\hline Up-flow & Seafood & 83 & $105 \mathrm{~mW} / \mathrm{m}^{2}$ & [112] \\
\hline Up-flow CW-MFC & Synthetic & 99 & $93 \mathrm{~mW} / \mathrm{m}^{3}$ & [113] \\
\hline Dual & Spent caustic & 98 & $82.1 \mathrm{mV}$ & [114] \\
\hline Dual & Combined industrial & 77.4 & $769 \mathrm{mV}$ & [115] \\
\hline 2 dual in parallel & Agro-food & 80 & $27.3 \mathrm{~W} / \mathrm{m}^{3}$ & [116] \\
\hline Dual & Brewery & 82 & $8.001 \mu \mathrm{W} / \mathrm{cm}^{2}$ & [117] \\
\hline MBR-dual & Synthetic & 90 & $1358 \mathrm{~mW} / \mathrm{m}^{3}$ & [118] \\
\hline Dual & Yeast & 90 & $6.1 \mathrm{~mW}$ & [119] \\
\hline Dual & Rice mill & 85.22 & $656.1 \mathrm{~mW} / \mathrm{m}^{3}$ & [120] \\
\hline Dual & Vegetable oil & 80 & $5839 \mathrm{mV}$ & [121] \\
\hline Stacked MFC & Daily & 52 & $290 \mathrm{~mW} / \mathrm{m}^{2}$ & [122] \\
\hline 96 tubular duals & Municipal & 75 & $200 \mathrm{~mW}$ & [123] \\
\hline 4 single & Domestic & 54.2 & $300 \mathrm{~mW} / \mathrm{m}^{2}$ & [124] \\
\hline Single & Yogurt & 87 & $1043 \mathrm{~mW} / \mathrm{m}^{2}$ & [125] \\
\hline Up-flow single & Dairy & 94 & $3.5 \mathrm{~W} / \mathrm{m}^{3}$ & [126] \\
\hline Single & Tannery & 88 & $7 \mathrm{~mW} / \mathrm{m}^{2}$ & [127] \\
\hline
\end{tabular}


Traditional wastewater treatment technologies for municipal and industrial waste under aerobic conditions consume a huge amount of energy and resources. As a result, large amounts of surplus sludge are produced, which must be treated. In comparison to current technologies, using microbial fuel cells for treating wastewater has many advantages. While purifying wastewater, MFCs are capable of recovering chemical energy and converting it into electricity. Furthermore, MFC technology consumes far less energy and produces far less sludge compared to other traditional technologies. Sludge disposal is well-known to be costly, and it significantly raises water treatment costs. Microorganisms consume all the energy from organic compounds in an aerobic process, but only a small part of this energy is available to them for growth. On the other hand, the majority of the energy is converted into electrical power in MFCs. In a subsequent step, the energy produced by MFCs can be reused as feedback energy in the same wastewater treatment process. Some xenobiotic compounds can also be metabolized by MFCs.

Early in 1991, MFC technology was considered applicable and efficient for wastewater treatment. Since then, wastewater from various sources that are high in organic materials have been applied successfully as a fuel source in MFCs. Large amounts of organic compounds can be found in sewage and industrial wastewater, which can be used as fuel in MFCs [128].

\subsection{Municipal or Domestic Wastewater Treatment via MFCs}

The high cost and low output energy of MFCs are considered a huge concern for their potential use in wastewater treatment. Koffi and Okabe [129] synthesized serpentine upflow MFCs with a polyvinylidene fluoride (PVDF)-based activated carbon (AC) air-cathode (MFC-PVDF/AC) that have been continuously operated for over 6 months with real domestic wastewater as a substrate. Without significant water leakage, the MFC-PVDF/ACs developed by the authors achieved average total COD removal rates $\left(5.11-0.94 \mathrm{~kg} \mathrm{tCOD} / \mathrm{m}^{3} / \mathrm{d}\right)$ and power densities (3.96-3.01 W/ $/ \mathrm{m}^{3}$ ) that were even higher than those of MFCs fitted with Pt-based air-cathodes (MFC-Pts). In addition, the authors have created a low-voltage booster (LVB) to raise the low output voltage of MFC-PVDF/ACs, which is less than $0.4 \mathrm{~V}$. The authors have successfully increased the voltage from less than $0.4 \mathrm{~V}$ to $4.35-5.2 \mathrm{~V}$, which is capable of turning on three LED bulbs for more than 12 days. The results of this study show that the developed MFC-PVDF/AC and the LVB circuit have superb performance for municipal wastewater treatment and functional power generation, indicating that it could be successfully implemented in the wastewater treatment industry [129]. In a further study, Corbella et al. [130] evaluated the possible usage of constructed wetland microbial fuel cells (CW-MFC) as a COD evaluation method for domestic wastewater. The authors in this study used four lab-scale CW-MFCs that were set up and fed with different COD concentrations of pre-settled domestic wastewater. Two diverse anodic materials were examined under laboratory conditions (graphite rods and gravel). The results of the study show that, due to a lack of precision after several weeks of use, the CW-MFC can be applied as a method for qualitative continuous influent water quality assessment [130].

The cost of using Nafion as a proton exchange membrane in MFCs is high, and operational issues such as biofouling and fuel crossover restrict the device's use in harvesting energy from domestic wastewaters. Das et al. [131] have used poly(vinyl alcohol) (PVA) cross-linked with glutaraldehyde (GA) as a relatively low-cost and efficient membrane for MFCs, a simple route adapted to fabricate a Nafion-alternative membrane. The results of the authors' study show that the power density of the cross-linked membrane was greater than that of domestic wastewater-fed MFCs, with a maximum of $158.28 \mathrm{~mW} / \mathrm{m}^{2}$ for the fabricated membrane. Consequently, based on its efficiency and low installation cost, the PVA-GA membrane with antimicrobial activity, high power performance, and negligible fuel crossover shows promise as a separator in future MFCs [131].

Nutrient recovery has emerged as a viable choice for addressing the crucial issue of producing fertilizers, which is a critical component of a country's food protection. Because of its massive nutrient-rich base and quantity, municipal wastewater has the ability to be a 
major source of nutrients that can be recovered. As a significant candidate that can both recover nutrients and produce electricity, MFCs have been arousing interest. Ye et al. [132] designed and operated a two-chambered MFC in a continuous flow mode using artificial municipal wastewater as a substrate. The impacts of hydraulic retention time (HRT) on MFC nutrient recovery were investigated by the authors. The results of the authors' study show that the fabricated MFC in this study is a very promising strategy for removing organic matter, recovering nutrients, and producing electricity [132].

Vélez-Pérez et al. [96] evaluated the efficiency of dual-chamber microbial fuel cells in the co-treatment of industrial acid mine drainage (I-AMD) and municipal wastewater (MWW) (DC-MFC). In the anodic chamber, MWW and sewage sludge were used as inoculum-fuel. The cathode side of the chamber was fed with I-AMD. The results of the authors' study demonstrates that the organic matter removal efficiency was approximately $15 \%$, and the wastewater alkalinity was decreased by greater than $50 \%$. In addition, the $\mathrm{SO}_{2}{ }^{-4}$ concentration was decreased by up to $20 \%$ and $\mathrm{NO}_{3}{ }^{-}$concentration was decreased by more than $90 \%$. Moreover, several metalloid and heavy metal (HMs) removal values were shown in the cells: $84 \%$ for $\mathrm{Cu}, 77 \%$ for $\mathrm{Al}, 71 \%$ for $\mathrm{Fe}, 55 \%$ for $\mathrm{Pb}, 42 \%$ for $\mathrm{Cd}$, and $42 \%$ for As. Finally, DC-MFC-A achieved a high power of $14,000 \mathrm{~mW} / \mathrm{m}^{3}$. The DC-MFCs were able to treat MWW, partially neutralize I-AMD, remove HMs, and generate bioelectricity all at the same time. As a result, DC-MFCs appear to be a promising bioremediation option for both MWW and I-AMD [96]. Liang [93] installed a 1000 L system of modularized MFCs for the treatment of practical municipal wastewater. The installed MFC was tested for over a year in two municipal wastewater treatment plants (MWTPs) under two distinct water flow connections to analyze their treatment capability for wastewater with both low and high initial COD concentrations. The COD removal rate in the MFC system was 70-90\%, and the concentration of the COD in the MFC effluent has remained less than $50 \mathrm{mg} \mathrm{L}^{-1}$. Additionally, when the MFC system was fed with artificial wastewater, it resulted in a maximum power density of $125 \mathrm{~W} \mathrm{~m}^{-3}$; while using municipal wastewater, it produced a range of $7-60 \mathrm{~W} \mathrm{~m}^{-3}$. Hence, according to the results of this study, the modularized MFC constructed has promising potential in the treatment of municipal wastewater [93].

The usage of a flat-panel air-cathode microbial fuel cell (FA-MFC) has been known to decrease the biodegradability and conductivity of domestic waste. Park et al. [133] used FA-MFCs with three anode spacing conditions and different flow rates to test the normalized energy recovery (NER) based on the volume of wastewater treated (NERV) and chemical oxygen demand (COD) removal (NERCOD). The results of the authors' study show that, at different spacings, current generation was the same; however, the removal of COD was influenced by the flow rates. Furthermore, in all anode spacing conditions, the NERV for both domestic wastewater and acetate showed strong agreement with flow rates. Independent of anode spacing, the NERCOD findings had a negative correlation with the removal rates of the COD. Consequently, this study demonstrates that FA-MFC is a very efficient candidate for an energy-efficient wastewater treatment technology [133].

Over the last decades, the use of constructed wetlands as microbial fuel cells (CWMFCs) has been gaining popularity to increase wastewater treatment efficiency while also producing electricity. However, the knowledge about the design and operation of CWMFCs is still lacking and needs to be studied well, specifically for real domestic wastewater treatment. Hence, Corbella [134] aimed to quantify the degree to which membrane-less MFCs improved treatment efficiency by simulating the core of a shallow, un-planted, horizontal, subsurface flow-constructed wetland. The authors set up six membrane-less MFCs in the lab and filled them with domestic wastewater in batch mode for 13 weeks. The results of the study showed that regardless of the anode material used, the best operating condition for maximizing MFC treatment performance was 220. Hence, this study shows that the use of constructed wetlands as MFCs is an efficient strategy for increasing the efficiency of domestic wastewater treatment [134]. Table 4 shows the performance of various types of MFCs in domestic wastewater treatment applications, proving the efficiency of MFCs in this treatment application. 
Table 4. Performance of MFCs in domestic wastewater.

\begin{tabular}{|c|c|c|c|c|}
\hline Type of MFC & $\begin{array}{l}\text { Maximum Power } \\
\text { Density }\left(\mathrm{mW} / \mathrm{m}^{2}\right)\end{array}$ & COD Removal (\%) & COD Reduction (\%) & Reference \\
\hline Air-cathode MFC & $10^{3}$ & 71.0 & - & [135] \\
\hline $\begin{array}{l}\text { Two-chamber MFC } \\
\text { Combining four MFC } \\
\text { reactors and an } \\
\text { AFMBR }\end{array}$ & 25 & 30.0 & - & [136] \\
\hline $\begin{array}{l}\text { Single-chamber } \\
\text { air-cathode MFC }\end{array}$ & 464 & $40.0-50.0$ & - & [137] \\
\hline $\begin{array}{ll}- & \text { SEA MFC } \\
- & \text { SPA MFC }\end{array}$ & $\begin{array}{ll}\text { - } & 328 \pm 11 \\
\text { - } & 282 \pm 29\end{array}$ & - & $\begin{array}{ll}\text { - } & 62.0 \pm 4.0 \% \text { to } 94.0 \pm 1.0 \% \\
\text { - } & 81.0 \pm 5.0 \% \text { to } 93.0 \pm 3.0 \%\end{array}$ & [138] \\
\hline Air-cathode MFC & 420 & - & 44 & [139] \\
\hline $\begin{array}{l}\text { Stackable horizontal } \\
\text { MFC (SHMFC) }\end{array}$ & 116 & $79.0 \pm 7.0$ & - & {$[140]$} \\
\hline $\begin{array}{l}\text { Single-chamber } \\
\text { microbial fuel cell } \\
\text { (SCMFC) }\end{array}$ & 26 & 80 & - & [141] \\
\hline $\begin{array}{l}\text { Flat plate MFC } \\
\text { (FPMFC) }\end{array}$ & $72 \pm 1$ & 42 & - & [142] \\
\hline $\begin{array}{c}\text { Air-biocathode } \\
\text { microbial fuel } \\
\text { cell-membrane } \\
\text { bioreactor (MFC-MBR) }\end{array}$ & 0.38 & 97 & - & {$[143]$} \\
\hline
\end{tabular}

\subsection{Industrial Wastewater}

The microbial fuel cell (MFC) technology has piqued the interest of researchers in the last few years as a means of producing bioenergy while also treating wastewater. In order to be practical, these devices need low-cost cathode catalysts for the reaction of oxygen reduction. The use of MFCs for industrial wastewater treatment, which typically contains several contaminants, is gaining great attraction. Ortiz-Martínez et al. [144] investigated the application of mixed manganese oxides with copper and nickel synthesized by coprecipitation for use in MFC devices fed with industrial wastewater. The new catalysts were tested based on their ability to remove chemical oxygen and their power production. The oxide with the formula $\mathrm{NiMn}_{2} \mathrm{O}_{4}$ performed well in terms of power density, achieving $80 \%$ of the power density obtained with $\mathrm{Pt}$. With no prior pretreatment, substantial COD removal from industrial wastewater was achieved after $168 \mathrm{~h}$ of operation [144]. Srikanth et al. [145] investigated the treatment of refinery wastewater (RW) using microbial fuel cells (MFC) in a batch mode, then continuous mode, with hydraulic retention times of 8 and $16 \mathrm{~h}$ (HRT), respectively. The output of the MFC was assessed by the authors in terms of power density, organics removal, particular pollutants removal, and the efficiency of energy conversion in relation to the operation mode. The results of the authors' study show that during continuous mode operation, a higher power density of $225 \pm 1.4 \mathrm{~mW} / \mathrm{m}^{2}$ was observed, and a high substrate degradation of $84.4 \pm 0.8 \%$. Furthermore, the batch mode operation demonstrated high substrate degradation $(81.8 \pm 1.8 \%)$. Overall, the current study demonstrated the feasibility of using RW as a power generation substrate in MFCs, as well as its treatment [145]. In a microbial fuel cell (MFC) using a selectively enriched hydrogen-generating (acidogenic) mixed culture, the generation of bioelectricity from anaerobic chemical wastewater treatment was assessed in a further study by Venkata Mohan et al. [146]. The MFC productivity was assessed by the authors via the usage of non-coated plain graphite electrodes at two organic/substrate loading rates in terms of 
wastewater treatment and bioelectricity production in an acidophilic microenvironment at ambient pressures and temperatures. The results of this study show that in situ bioelectricity generation and wastewater treatment are both feasible. The applied OLR was found to affect the performance of MFCs in terms of power generation and wastewater treatment. At stable operating conditions, maximum voltages of $716 \mathrm{mV}$ and $731 \mathrm{mV}$ were observed by the authors. At applied $50 \Omega$ resistance, the maximum power yield $\left(0.73 \mathrm{~W} / \mathrm{kg} \mathrm{COD}_{\mathrm{R}}\right.$ and $\left.0.49 \mathrm{~W} \mathrm{~kg} / \mathrm{COD}_{\mathrm{R}}\right)$ and current density $\left(339.87 \mathrm{~mA} / \mathrm{m}^{2}\right.$ and $\left.355.43 \mathrm{~mA} / \mathrm{m}^{2}\right)$ were also observed. This study shows that the designed MFC is capable of wastewater treatment and bioelectricity generation [146].

Efficient wastewater treatment and processes with long-term energy efficiency are two of the most pressing concerns in the liquid waste management industry today. Agroindustrial wastewater contains high-strength organic contaminants that, if not treated properly, can have negative consequences on the receiving water bodies. Microbial fuel cells (MFCs) combine wastewater treatment with direct chemical-to-electrical energy conversion. As a result of the organic matter content and biodegradability, wastewater from the agrofood industry appears to be especially promising [147]. Hence, Cecconnet et al. [116] aimed in their study to determine the bioelectrochemical treatability of dairy wastewater by MFCs, as well as the operational effects on MFC electrical efficiency and possible strategies for reducing overpotentials. The authors operated two parallel MFC reactors fed with undiluted dairy wastewater in continuous control for 2.5 months. The results of this study show that MFCs can treat these types of industrial effluents with high organic matter removal and recover a maximum power density of greater than $27 \mathrm{~W} / \mathrm{m}^{3}$. Thus, energy recovery from organic waste treatment is a viable method for pursuing renewable technologies [116].

Environmentalists are usually facing a global challenge in safely disposing polluted water. Present treatment systems are insufficiently capable of addressing wastewater contamination and meet the ever-increasing demand for water sanitation. The microbial fuel cell (MFC), on the other hand, is a modern technology that not only treats wastewater but also produces electricity. Firdous et al. [121] examined the generation of electricity by a dual-chambered MFC during wastewater treatment of vegetable oil industries in Pakistan. The microbial fuel cells were studied in the lab by the authors at two different temperatures $\left(25\right.$ and $35^{\circ} \mathrm{C}$ ). The authors mentioned that, in a two-compartment MFC reactor, a proton exchange membrane separated the anaerobic anode and aerobic cathode chambers. A total of 20 wastewater samples from vegetable oil industrial effluents were obtained and treated in MFC for $72 \mathrm{~h}$. The efficiency of the MFC improved as the temperature and time were increased, according to the results of this study. At $35{ }^{\circ} \mathrm{C}$, the highest chemical oxygen demand (COD) removal efficiency reached was 80 to $90 \%$ while the maximum voltage was $5839 \mathrm{mV}$. This study demonstrates that MFCs are capable of treating industrial wastewater efficiently [121].

\subsection{Brewery Wastewater}

Microbial fuel cells and electro-active bacteria are used to obtain chemical energy from wastewater, making wastewater a potential renewable energy source [148-154]. Various brewery industries discharge wastewater into the environment, causing severe problems to the environment. Negassa et al. [151] demonstrated, by inoculating locally isolated microorganisms into double-chamber MFCs, the treatment of brewery wastewater while also developing bioelectricity. The authors have extracted microorganisms locally from brewery wastewater, brewery waste sludge, and food processing waste sludge. The results of the authors' study shows that the isolated microorganisms from brewery waste sludge have performed better than the bacteria isolated from brewery wastewater and food processing industry waste sludge. Moreover, MFCs with the isolated microorganisms from brewery waste sludge resulted in a maximum power densities of $0.8 \mathrm{~W} / \mathrm{m}^{3}$ and $0.35 \mathrm{~W} / \mathrm{m}^{3}$ using synthetic and real brewery wastewater, respectively. Furthermore, the maximum COD removal efficiency was $83 \%$. This study demonstrates that a treatment of 
brewery wastewater should be attained via locally isolated microorganisms to produce clean and renewable energy [151]. Liu et al. [153] developed a UASB-MFC dual sensors system to treat brewery wastewater. The MFCs developed in this study have a voltage range of $0.34-0.42 \mathrm{~V}$, a COD removal rate of about $90 \%$, and an $\mathrm{NH}_{4}^{+}-\mathrm{N}$ concentration of less than $15 \mathrm{mg} / \mathrm{L}$. The long-term performance of MFCs was studied by the authors using electrochemical methods, and it was discovered that biosensor degradation was primarily caused by $\mathrm{Ca}^{2+}$ and $\mathrm{Mg}^{2+}$ precipitation on the cathode surface, which was influenced by concentration. Hence, cleaning the electrode using a self-enhanced method that does not require external assistance ECS (electrode connection switching) will boost the efficiency of MFCs to $83.2-84.6 \%$ [153].

Microbial fuel cells (MFCs) have been demonstrated as an efficient wastewater treatment system. Integrating MFCs into present wastewater treatment plants can lower operating costs while also improving treatment efficiency, and the scaling up of MFCs will be critical. However, only a small number of studies have recorded successful scale-up efforts. Before MFCs can be commercialized, the fabrication costs, treatment efficiency, and operating lifetime must all be optimized. To examine these factors, a 20-L MFC system with two 10-L MFC reactors was operated for almost one year with brewery wastewater by Lu et al. [154]. The highest COD removal efficiency attained by the authors was $94.6 \pm 1.0 \%$. Thus, based on this study, MFCs are capable of supporting several rates of treatment over a long time period and are successful enough in maintaining high efficiency treatment processes [154].

\section{Nutrient Removal in MFCs}

\subsection{Nitrogen Removal in MFCs}

The removal of nitrogen from wastewater is a critical process that requires large amounts of energy, necessitating the development of more energy-efficient treatment methods. Koffi and Okabe [155], electrically operated a single-chamber microbial electrolysis cell (MEC) using a double-chamber microbial fuel cell (MFC) to investigate the removal efficiency of bioelectrochemical ammonium nitrogen $\left(\mathrm{NH}_{4}{ }^{+}-\mathrm{N}\right)$ from real municipal wastewater without requiring aeration with large amounts of energy. At several applied voltages, the total nitrogen (TN) removal rates were obtained by the authors. The results of the authors' study show that, without aeration and at a voltage of $0.8 \mathrm{~V}$, a TN removal rate of $95 \pm 42 \mathrm{~g}-\mathrm{TN} \mathrm{m}{ }^{-3} \mathrm{~d}^{-1}$ was achieved. The nitrogen removal rates obtained in this study are greater than the previously recorded values in past studies. Thus, the MFC-driven single-chamber MEC provided by this study is a successful method for the removal of nitrogen from wastewater [155].

The residual nitrogen present in the effluents of municipal wastewater degrades the aquatic systems, and the addition of an external source of carbon is the most commonly used approach to fix this issue. The external carbon sources that are mostly used by wastewater treatment industries that are limited on carbon are agricultural biomasses, due to their low cost and high availability. Hence, the feasibility of introducing agricultural wastes in a microbial fuel cell-constructed wetland (MFC-CW) to optimize the production of bioelectricity and the removal of nitrogen was estimated, and the results obtained were compared by the authors to those in an MFC study by Tao et al. [156]. Several agricultural wastes, including corncobs, rice husks, and straw, were compared by the authors, and the corncob turned out to release more carbon. The results of the authors' study show that corncob carbon release was a diffusion process, with the highest COD removal of $47.6 \mathrm{mg}(\mathrm{gL})^{-1}$ fitting a second-order kinetics. Corncob addition improved nutrient removal dramatically in MFC-CWs with an original influent COD of $22 \mathrm{mg} \mathrm{L}^{-1}$, with an overall total nitrogen $(\mathrm{TN})$, nitrate nitrogen $\left(\mathrm{NO}_{3}-\mathrm{N}\right)$, and ammonia nitrogen $\left(\mathrm{NH}_{4}{ }^{+}-\mathrm{N}\right)$ removal of $86.6 \pm 1.6 \%$, $97.2 \pm 0.3 \%$, and $73.1 \pm 2.8 \%$, respectively. Furthermore, the production of bioelectricity was improved with a maximum power density of $23.5 \mathrm{~mW} / \mathrm{m}^{3}$, despite a small increase in internal resistance. This study proves that when treating carbon-limited wastewater, 
MFC-CW can remove nitrogen, recover electricity, and handle agricultural wastes in a cost-effective manner [156].

\subsection{Sulphate Removal MFC}

In a MFC, the mass balance of organic matter, reaction kinetics, and sulphate transformation are studied by changing the sulphate and the COD concentrations in the substrate. Experiments show that in a MFC with an inlet COD/sulphate ratio of 0.75 , a sulphate removal greater that $99 \%$ can be reached, yielding about $1.33 \mathrm{~kg} / \mathrm{m}^{3}$ COD removal per day. These fascinating results make MFC an interesting sulphate removal technique [157]. Various research studies have focused their work on the removal of sulphates from wastewater. Chakraborty et al. [158] demonstrated that sodium dodecyl sulphate (SDS) can be biodegraded effectively in MFC after a 12-h retention period. This was the first to quantify the use of MFCs for SDS degradation and its effect on MFC power generation and organic matter removal capability. The SDS-induced microbial diversification of the anodic biofilm was also demonstrated in this study, which correlates with the established SDS degradation pathway. The authors have successfully reached more than $70 \%$ SDS removal efficiency in their study [158].

MFCs have been previously applied in the conversion of carbon-based substrates into electricity. Sulfur compounds, on the other hand, are abundant in organic waste and wastewater. Rabaey et al. [159] converted dissolved sulfide to elemental sulfur by using a MFC with a hexacyanoferrate cathodic electrolyte. Two types of MFCs were used by the authors: a square type with a closed cathode compartment, and a tubular type with an open cathode compartment. In addition, MFCs were attached to an anaerobic up-flow anaerobic sludge blanket reactor, resulting in total sulfide and acetate removals of up to $98 \%$ and $46 \%$, respectively. The results of the authors' study show that the MFCs were successfully able to simultaneously remove sulfate via sulfide [159]. Furthermore, sulfate-reducing bacteria (SRB) can be used to biologically remove sulfur via reducing sulfate to sulfide, which is then oxidized into elemental sulfur $(\mathrm{S}(0)$ ) by sulfide-oxidizing bacteria $(\mathrm{SOB})$ for recovery. Lee et al. [160] treated, in their study, sulfate+organic carbon wastewaters using a MFC cultivated with the SRB+SOB anodic biofilm. The results of the authors' study show that the SRB cells in the biofilm have efficiently converted excess sulfate ions to sulfide, and the generated sulfide was then diffused to the neighboring SOB cells, where it was converted to elemental sulfur $S(0)$. The electron flux of the MFC was primarily determined by cell-to-cell sulfide transport [160].

\section{Metal Removal in MFCs}

In the last 15 years, the bio-electrochemical technology of microbial fuel cells has arisen as a modern and appealing technology that presents a new pathway for the generation of electricity and the removal and recovery of heavy metals from wastewater. The MFC approach precedes the traditional techniques in the following manner: it is energy intensive, produces less amounts of sludge, and has low efficacy at high concentrations. Studies demonstrate that the $\mathrm{pH}$, mixed metal systems, the gas environment in the cathode, the composition of the biofilm, and the metal redox potential all have a major effect on the effectiveness of MFCs in the removal and recovery of metal and the generation of power [161].

The removal and recovery of organic pollutants using MFCs is a clean approach for industries to develop greener technologies. Lim et al. [162] investigated the ability of MFCs to remove zinc from industrial effluents. The results of the authors' study show that, for industrial and synthetic samples and after $22 \mathrm{~h}$ of operation, the removal of $\mathrm{Zn}^{2+}$ in MFCs was greater $96 \%$. Furthermore, in the industrial samples, the electroprecipitation process was found to be more dominant than the electrodeposition process. According to the findings of this study, MFCs can be used to remove heavy metals in a safe and environmentally friendly manner without the use of electricity or chemical inputs [162]. In a further study, Wang et al. [163] used an up-flow constructed wetlands-microbial fuel cell 
(CW-MFC) to characterize a microbial community structure and resistance gene (CzcA) for the treatment of wastewater that is contaminated with $\mathrm{Zn}$ (II). The results of the authors' study show that the CW-MFC had a high Zn (II) and COD removal efficiency, in addition to a high power density [163].

Wastewater treatment and precious metals recovery via MFCs offers an appealing solution for a cleaner environment and industrial processes. Recovering silver from wastewater and valorization as silver nanoflakes (AgNFs) aids in the transformation from linear to circular economies by bringing waste material back into the production stream. Ali et al. [164] compared a MFC that is fed with silver-laden artificial wastewater (MFC-Ag) to a MFC fed with potassium ferricyanide (MFC-FC) and a MFC fed with phosphate buffer as catholyte (MFC-blank) in terms of bioelectrochemical performance. The authors' study results demonstrate that the silver removal and recovery efficiencies after $72 \mathrm{~h}$ of operation of MFC-Ag has reached $83 \pm 0.7 \%$ and $67.8 \pm 1$, respectively. Furthermore, the MFC-Ag has appeared to have a greater maximum power density and current density compared to MFC-FC and MFC-blank. Additionally, MFC-Ag has a high coulombic efficiency and a low solution resistance, indicating that silver-laden wastewater has the potential for large-scale applications. This study offers a broad range of applications for scaling up the technology of MFCs with greater sustainability and limited facilities [164].

\section{Challenges and Future Perspectives}

Based on the published research, MFC systems offer great potential for sustainable wastewater treatment in addition to energy production. Although the studies published in this regard state the possible advantages of the system, a full-scale application is still in the early stages of use, and further optimization and scale-up studies are required.

As the current produced by the MFC cells depends on the ability of the used microorganisms to oxidize the available substrate and the effective transfer of the electrons between the electrodes, the efficiency depends on many variables. The type of waste used and its composition play an important role in influencing the resultant energy produced. In addition, other experimental variables related to the cell design, electrode types, and set-up conditions can easily affect the resultant bioelectricity production and degree of wastewater and pollutant degradation. Energy production is also heavily dependent on the type of substrate used, its initial concentration, and other operational parameters such as $\mathrm{pH}$ and temperature. Optimizing all such variables and a lack of consistency remains a main challenge for scaling up long-term industrial operations. Another main hindrance is associated with the costs related to the exchange membranes. Furthermore, regular cleaning to remove any biofouling deposits from the membranes can incur additional costs and provide high and undesirable resistance to electron movement, affecting power generation. The main costs are also associated with the expensive metal catalyst (for example, platinum). Alternative non-platinized cathodes are required and research studies are being conducted to find suitable replacements with similar performance to platinum. Manganese dioxide, stainless steel, and nickel alloys are cathode catalysts that may offer a great alternative to platinized ones. In addition, and as a main potential for the use of MFCs, is the fact that there has been a huge improvement in the power production of the MFC systems since its early reports in 2004. Further optimization in the future is expected to make MFCs a great contender in sustainable wastewater treatment, compared, for example, to anaerobic digestion.

MFCs have been shown in several studies to be an efficient candidate for the removal of various pollutants. Some limitations of MFCs for wastewater treatment should be further explored, including high cost and energy requirements. In order to further enhance the performance of wastewater treatment, more research should be focused on new MFC materials. Finally, a deeper understanding of the nature and role of electrode materials is needed. By advancing MFCs alone or in conjunction with other methods, multiform wastewater can be substantially degraded. 


\section{Conclusions}

Wastewater is widely acknowledged as a significant source of contamination in the world. However, treating and recovering wastewater is hard to attain and maintain because most of the present wastewater treatment systems require large amounts of energy and are very expensive to build and operate. Thus, an alternative approach using microbial fuel cells (MFCs) is greatly investigated currently as a cost-effective and energy efficient pathway in the wastewater treatment field.

This review highlighted the main factors that still hinder the scaling up of this technology. The main issues can be summarized as:

1. Costs associated with platinum electrodes;

2. Biofouling effects on the membranes;

3. Non-consistence power generation depending on the type of substrate and operational conditions;

4. Monitoring and harvesting the power generated in the system.

In this review paper, the applications of MFCs in the removal of nutrients (nitrogen and sulphates) and precious metals from wastewater were also intensively reviewed. As a result, the efficacy of various MFCs in achieving sustainable power generation from wastewater has been critically addressed in this study. MFCs precede several other wastewater treatment methods in the following manner: they produce less sludge, require less energy to operate, and produce large amounts of energy. MFCs are also limited in their practical application due to the high cost of mediators and exchange membranes.

Author Contributions: Conceptualization, M.K. and S.E.; methodology, S.E.; validation, M.K. and F.A.; writing-original draft preparation M.K. and S.E.; writing-review and editing, S.E., M.K., F.A., M.K.H., M.A.-G.; visualization, S.E., M.K., F.A., M.K.H., M.A.-G.; supervision, M.K.; project administration, M.K.; funding acquisition, M.K. All authors have read and agreed to the published version of the manuscript.

Funding: This publication was possible with the fund from QUCG-CENG 21/22-4. In addition, the work was made possible by a grant from the Qatar National Research Fund under the National Priorities Research Program, award number NPRP12S-0306-190247.

Institutional Review Board Statement: Not applicable.

Informed Consent Statement: Not applicable.

Data Availability Statement: Not applicable.

Conflicts of Interest: The authors declare no conflict of interest.

\section{References}

1. Baz, K.; Cheng, J.; Xu, D.; Abbas, K.; Ali, I.; Ali, H.; Fang, C. Asymmetric impact of fossil fuel and renewable energy consumption on economic growth: A nonlinear technique. Energy 2021, 226, 120357. [CrossRef]

2. Gani, A. Fossil fuel energy and environmental performance in an extended STIRPAT model. J. Clean. Prod. 2021, 297, 126526. [CrossRef]

3. Fathi, B.; Ashena, M.; Bahari, A.R. Energy, environmental, and economic efficiency in fossil fuel exporting countries: A modified data envelopment analysis approach. Sustain. Prod. Consum. 2021, 26, 588-596. [CrossRef]

4. Paraschiv, S.; Paraschiv, L.S. Trends of carbon dioxide $\left(\mathrm{CO}_{2}\right)$ emissions from fossil fuels combustion (coal, gas and oil) in the EU member states from 1960 to 2018. Energy Rep. 2020, 6, 237-242. [CrossRef]

5. Elshobary, M.E.; Zabed, H.M.; Yun, J.; Zhang, G.; Qi, X. Recent insights into microalgae-assisted microbial fuel cells for generating sustainable bioelectricity. Int. J. Hydrog. Energy 2021, 46, 3135-3159. [CrossRef]

6. Obileke, K.; Onyeaka, H.; Meyer, E.L.; Nwokolo, N. Microbial fuel cells, a renewable energy technology for bio-electricity generation: A mini-review. Electrochem. Commun. 2021, 125, 107003. [CrossRef]

7. Pandit, S.; Savla, N.; Sonawane, J.M.; Sani, A.M.; Gupta, P.K.; Mathuriya, A.S.; Rai, A.K.; Jadhav, D.A.; Jung, S.P.; Prasad, R. Agricultural waste and wastewater as feedstock for bioelectricity generation using microbial fuel cells: Recent advances. Fermentation 2021, 7, 169. [CrossRef]

8. Uddin, M.J.; Jeong, Y.-K.; Lee, W. Microbial fuel cells for bioelectricity generation through reduction of hexavalent chromium in wastewater: A review. Int. J. Hydrog. Energy 2021, 46, 11458-11481. [CrossRef] 
9. Hoang, A.T.; Nižetić, S.; Ng, K.H.; Papadopoulos, A.M.; Le, A.T.; Kumar, S.; Hadiyanto, H.; Pham, V.V. Microbial fuel cells for bioelectricity production from waste as sustainable prospect of future energy sector. Chemosphere 2022, 287, 132285. [CrossRef]

10. Zhang, Z.; Zeng, Y.; Zheng, N.; Luo, L.; Xiao, H.; Xiao, H. Fossil fuel-related emissions were the major source of NH3 pollution in urban cities of northern China in the autumn of 2017. Environ. Pollut. 2020, 256, 113428. [CrossRef]

11. Fors, Y.; Nilsson, T.; Risberg, E.D.; Sandström, M.; Torssander, P. Sulfur accumulation in pinewood (Pinus sylvestris) induced by bacteria in a simulated seabed environment: Implications for marine archaeological wood and fossil fuels. Int. Biodeterior. Biodegrad. 2008, 62, 336-347. [CrossRef]

12. Nigri, E.M.; Santos, A.L.A.; Rocha, S.D.F. Removal of organic compounds, calcium and strontium from petroleum industry effluent by simultaneous electrocoagulation and adsorption. J. Water Process Eng. 2020, 37, 101442. [CrossRef]

13. Shi, J.; Huang, W.; Han, H.; Xu, C. Pollution control of wastewater from the coal chemical industry in China: Environmental management policy and technical standards. Renew. Sustain. Energy Rev. 2021, 143, 110883. [CrossRef]

14. Nie, A.; Kung, S.-S.; Li, H.; Zhang, L.; He, X.; Kung, C.-C. An environmental and economic assessment from bioenergy production and biochar application. J. Saudi Chem. Soc. 2021, 25, 101173. [CrossRef]

15. Baležentis, T.; Streimikiene, D.; Zhang, T.; Liobikiene, G. The role of bioenergy in greenhouse gas emission reduction in EU countries: An Environmental Kuznets Curve modelling. Resour. Conserv. Recycl. 2019, 142, 225-231. [CrossRef]

16. Meyer, M.A.; Leckert, F.S. A systematic review of the conceptual differences of environmental assessment and ecosystem service studies of biofuel and bioenergy production. Biomass Bioenergy 2018, 114, 8-17. [CrossRef]

17. Abdallah, L.; El-Shennawy, T. Reducing Carbon Dioxide Emissions from Electricity Sector Using Smart Electric Grid Applications. J. Eng. 2013, 2013, 845051. [CrossRef]

18. Kurade, M.B.; Ha, Y.-H.; Xiong, J.-Q.; Govindwar, S.P.; Jang, M.; Jeon, B.-H. Phytoremediation as a green biotechnology tool for emerging environmental pollution: A step forward towards sustainable rehabilitation of the environment. Chem. Eng. J. 2021, 415, 129040. [CrossRef]

19. Ocampo-López, C.; Ramírez-Carmona, M.; Rendón-Castrillón, L.; Vélez-Salazar, Y. Applied research in biotechnology as a source of opportunities for green chemistry start-ups. Sustain. Chem. Pharm. 2019, 11, 41-45. [CrossRef]

20. Khandaker, S.; Das, S.; Hossain, M.T.; Islam, A.; Miah, M.R.; Awual, M.R. Sustainable approach for wastewater treatment using microbial fuel cells and green energy generation-A comprehensive review. J. Mol. Liq. 2021, 344, 117795. [CrossRef]

21. Borchert, E.; Hammerschmidt, K.; Hentschel, U.; Deines, P. Enhancing Microbial Pollutant Degradation by Integrating EcoEvolutionary Principles with Environmental Biotechnology. Trends Microbiol. 2021, 29, 908-918. [CrossRef] [PubMed]

22. Desireddy, S.; Sabumon, P.C.; Manasa, R.L.; Mehta, A. Development of an up-flow anoxic nano-biotechnological reactor for simultaneous removal of ammonia and COD from low C/N secondary treated wastewater. J. Water Process Eng. 2020, 36, 101344. [CrossRef]

23. Wang, C.; Huang, R.; Sun, R.; Yang, J.; Dionysiou, D.D. Microplastics separation and subsequent carbonization: Synthesis, characterization, and catalytic performance of iron/carbon nanocomposite. J. Clean. Prod. 2022, 330, 129901. [CrossRef]

24. Bednarek, A.; Szklarek, S.; Zalewski, M. Nitrogen pollution removal from areas of intensive farming-Comparison of various denitrification biotechnologies. Ecohydrol. Hydrobiol. 2014, 14, 132-141. [CrossRef]

25. Ding, Y.; Wang, W.; Liu, X.; Song, X.; Wang, Y.; Ullman, J.L. Intensified nitrogen removal of constructed wetland by novel integration of high rate algal pond biotechnology. Bioresour. Technol. 2016, 219, 757-761. [CrossRef]

26. Wang, C.; Huang, R.; Sun, R. Green one-spot synthesis of hydrochar supported zero-valent iron for heterogeneous Fenton-like discoloration of dyes at neutral pH. J. Mol. Liq. 2020, 320, 114421. [CrossRef]

27. Henriques, B.; Rocha, L.S.; Lopes, C.B.; Figueira, P.; Duarte, A.C.; Vale, C.; Pardal, M.A.; Pereira, E. A macroalgae-based biotechnology for water remediation: Simultaneous removal of $\mathrm{Cd}, \mathrm{Pb}$ and $\mathrm{Hg}$ by living Ulva lactuca. J. Environ. Manag. 2017, 191, 275-289. [CrossRef]

28. De Heyder, B.; Smet, E.; Verstraete, W.; Van Langenhove, H. Biotechnological Removal of Ethene from Waste Gases. In Studies in Environmental Science; Dragt, A.J., van Ham, J., Eds.; Elsevier: Amsterdam, The Netherlands, 1992; Volume 51, pp. $309-313$.

29. Hanley, Z.; Slabas, T.; Elborough, K.M. The use of plant biotechnology for the production of biodegradable plastics. Trends Plant Sci. 2000, 5, 45-46. [CrossRef]

30. Khardenavis, A.A.; Suresh Kumar, M.; Mudliar, S.N.; Chakrabarti, T. Biotechnological conversion of agro-industrial wastewaters into biodegradable plastic, poly $\beta$-hydroxybutyrate. Bioresour. Technol. 2007, 98, 3579-3584. [CrossRef]

31. Tamersit, S.; Bouhidel, K.-E. Treatment of tannery unhairing wastewater using carbon dioxide and zinc cations for greenhouse gas capture, pollution removal and water recycling. J. Water Process Eng. 2020, 34, 101120. [CrossRef]

32. Tamersit, S.; Bouhidel, K.-E.; Zidani, Z. Investigation of electrodialysis anti-fouling configuration for desalting and treating tannery unhairing wastewater: Feasibility of by-products recovery and water recycling. J. Environ. Manag. 2018, 207, 334-340. [CrossRef] [PubMed]

33. Shiu, H.-Y.; Lee, M.; Chiueh, P.-T. Water reclamation and sludge recycling scenarios for sustainable resource management in a wastewater treatment plant in Kinmen islands, Taiwan. J. Clean. Prod. 2017, 152, 369-378. [CrossRef]

34. Allinson, M.; Kadokami, K.; Shiraishi, F.; Nakajima, D.; Zhang, J.; Knight, A.; Gray, S.R.; Scales, P.J.; Allinson, G. Wastewater recycling in Antarctica: Performance assessment of an advanced water treatment plant in removing trace organic chemicals. $J$. Environ. Manag. 2018, 224, 122-129. [CrossRef] [PubMed] 
35. Tarrass, F.; Benjelloun, M.; Benjelloun, O. Recycling Wastewater after Hemodialysis: An Environmental Analysis for Alternative Water Sources in Arid Regions. Am. J. Kidney Dis. 2008, 52, 154-158. [CrossRef] [PubMed]

36. Ismail, Z.Z.; Al-Hashmi, E.A. Assessing the recycling potential of industrial wastewater to replace fresh water in concrete mixes: Application of polyvinyl acetate resin wastewater. J. Clean. Prod. 2011, 19, 197-203. [CrossRef]

37. Khatri, N.; Khatri, K.K.; Sharma, A. Enhanced Energy Saving in Wastewater Treatment Plant using Dissolved Oxygen Control and Hydrocyclone. Environ. Technol. Innov. 2020, 18, 100678. [CrossRef]

38. Wang, S.; Dai, Y.; Ma, Z.; Qi, H.; Chen, Z.; Shen, Y.; Yang, J.; Cui, P.; Wang, Y.; Zhu, Z.; et al. Application of energy-saving hybrid distillation-pervaporation process for recycling organics from wastewater based on thermoeconomic and environmental analysis. J. Clean. Prod. 2021, 294, 126297. [CrossRef]

39. Sabia, G.; Petta, L.; Avolio, F.; Caporossi, E. Energy saving in wastewater treatment plants: A methodology based on common key performance indicators for the evaluation of plant energy performance, classification and benchmarking. Energy Convers. Manag. 2020, 220, 113067. [CrossRef]

40. Zhu, Z.; Qi, H.; Shen, Y.; Qiu, X.; Zhang, H.; Qi, J.; Yang, J.; Wang, L.; Wang, Y.; Ma, Y.; et al. Energy-saving investigation of organic material recovery from wastewater via thermal coupling extractive distillation combined with heat pump based on thermoeconomic and environmental analysis. Process Saf. Environ. Prot. 2021, 146, 441-450. [CrossRef]

41. Borzooei, S.; Campo, G.; Cerutti, A.; Meucci, L.; Panepinto, D.; Ravina, M.; Riggio, V.; Ruffino, B.; Scibilia, G.; Zanetti, M. Optimization of the wastewater treatment plant: From energy saving to environmental impact mitigation. Sci. Total Environ. 2019, 691, 1182-1189. [CrossRef]

42. Torregrossa, D.; Hernández-Sancho, F.; Hansen, J.; Cornelissen, A.; Popov, T.; Schutz, G. Energy saving in wastewater treatment plants: A plant-generic cooperative decision support system. J. Clean. Prod. 2017, 167, 601-609. [CrossRef]

43. Yang, J.; Chen, B. Energy efficiency evaluation of wastewater treatment plants (WWTPs) based on data envelopment analysis. Appl. Energy 2021, 289, 116680. [CrossRef]

44. Munoz-Cupa, C.; Hu, Y.; Xu, C.; Bassi, A. An overview of microbial fuel cell usage in wastewater treatment, resource recovery and energy production. Sci. Total Environ. 2021, 754, 142429. [CrossRef] [PubMed]

45. Gadkari, S.; Shemfe, M.; Sadhukhan, J. Microbial fuel cells: A fast converging dynamic model for assessing system performance based on bioanode kinetics. Int. J. Hydrog. Energy 2019, 44, 15377-15386. [CrossRef]

46. Bajracharya, S.; Sharma, M.; Mohanakrishna, G.; Dominguez-Benetton, X.; Strik, D.; Sarma, P.; Pant, D. An overview on emerging bioelectrochemical systems (BESs): Technology for sustainable electricity, waste remediation, resource recovery, chemical production and beyond. Renew. Energy 2016, 98, 153-170. [CrossRef]

47. Caizán-Juanarena, L.; Borsje, C.; Sleutels, T.; Yntema, D.; Santoro, C.; Ieropoulos, I.; Soavi, F.; ter Heijne, A. Combination of bioelectrochemical systems and electrochemical capacitors: Principles, analysis and opportunities. Biotechnol. Adv. 2020, 39, 107456. [CrossRef]

48. Das, S.; Das, S.; Das, I.; Ghangrekar, M.M. Application of bioelectrochemical systems for carbon dioxide sequestration and concomitant valuable recovery: A review. Mater. Sci. Energy Technol. 2019, 2, 687-696. [CrossRef]

49. Ardakani, M.N.; Gholikandi, G.B. Microbial fuel cells (MFCs) in integration with anaerobic treatment processes (AnTPs) and membrane bioreactors (MBRs) for simultaneous efficient wastewater/sludge treatment and energy recovery -A state-of-the-art review. Biomass Bioenergy 2020, 141, 105726. [CrossRef]

50. Potter, M.C. Electrical Effects Accompanying the Decomposition of Organic Compounds. Proc. R. Soc. Lond. Ser. B Contain. Pap. Biol. Character 1911, 84, 260-276.

51. Davis, F.; Higson, S.P. Biofuel cells—Recent advances and applications. Biosens. Bioelectron. 2007, 22, 1224-1235. [CrossRef]

52. Adebule, A.; Aderiye, J.; Adebayo, A. Improving Bioelectricity Generation of Microbial Fuel Cell (MFC) With Mediators Using Kitchen Waste as Substrate. Ann. Appl. Microbiol. Biotechnol. J. 2018, 2, 1008. [CrossRef]

53. Sekrecka-Belniak, A.; Toczyłowska-Mamińska, R. Fungi-Based Microbial Fuel Cells. Energies 2018, 11, 2827. [CrossRef]

54. Rahimnejad, M.; Najafpour, G.; Ghoreyshi, A.A.; Talebnia, F.; Premier, G.; Bakeri, G.; Kim, J.R.; Oh, S.-E. Thionine increases electricity generation from microbial fuel cell using Saccharomyces cerevisiae and exoelectrogenic mixed culture. J. Microbiol. 2012, 50, 575-580. [CrossRef] [PubMed]

55. Gunawardena, A.; Fernando, S.; To, F. Performance of a Yeast-mediated Biological Fuel Cell. Int. J. Mol. Sci. 2008, 9, 1893-1907. [CrossRef]

56. Malarczyk, E.; Kochmanska-Rdest, J.; Jarosz-Wilkolazka, A. Influence of very low doses of mediators on fungal laccase activityNonlinearity beyond imagination. Nonlinear Biomed. Phys. 2009, 3, 10. [CrossRef] [PubMed]

57. Guo, Y.; Bruno, R.S. Endogenous and exogenous mediators of quercetin bioavailability. J. Nutr. Biochem. 2015, 26, 201-210. [CrossRef]

58. Lovley, D.R. Dissimilatory metal reduction. Annu. Rev. Microbiol. 1993, 47, 263-290. [CrossRef] [PubMed]

59. Kim, B.H.; Ikeda, T.; Park, H.S.; Kim, H.J.; Hyun, M.S.; Kano, K.; Takagi, K.; Tatsumi, H. Electrochemical activity of an Fe(III)reducing bacterium, Shewanella putrefaciens IR-1, in the presence of alternative electron acceptors. Biotechnol. Tech. 1999, 13, 475-478. [CrossRef]

60. Kothari, M.; Kulkarni, L.G.; Gupta, D.; Thombre, R. Extremophiles in Sustainable Bioenergy Production as Microbial Fuel Cells. In Physiology, Genomics, and Biotechnological Applications of Extremophiles; Gunjal, A., Thombre, R., Parray, J., Eds.; IGI Global: Hershey, PA, USA, 2022; pp. 286-307. [CrossRef] 
61. Niessen, J.; Harnisch, F.; Rosenbaum, M.; Schröder, U.; Scholz, F. Heat treated soil as convenient and versatile source of bacterial communities for microbial electricity generation. Electrochem. Commun. 2006, 8, 869-873. [CrossRef]

62. Zhang, E.; Xu, W.; Diao, G.; Shuang, C. Electricity generation from acetate and glucose by sedimentary bacterium attached to electrode in microbial-anode fuel cells. J. Power Sources 2006, 161, 820-825. [CrossRef]

63. Logan, B.E.; Murano, C.; Scott, K.; Gray, N.D.; Head, I.M. Electricity generation from cysteine in a microbial fuel cell. Water Res. 2005, 39, 942-952. [CrossRef]

64. Holmes, D.E.; Bond, D.R.; O'Neil, R.A.; Reimers, C.E.; Tender, L.R.; Lovley, D.R. Microbial communities associated with electrodes harvesting electricity from a variety of aquatic sediments. Microb. Ecol. 2004, 48, 178-190. [CrossRef]

65. Park, D.H.; Zeikus, J.G. Impact of electrode composition on electricity generation in a single-compartment fuel cell using Shewanella putrefaciens. Appl. Microbiol. Biotechnol. 2002, 59, 58-61. [CrossRef] [PubMed]

66. Choi, Y.; Jung, E.; Kim, S.; Jung, S. Membrane fluidity sensoring microbial fuel cell. Bioelectrochemistry 2003, 59, 121-127. [CrossRef]

67. Najafpour, G.; Rahimnejad, M.; Mokhtarian, N.; Wan Daud, W.; Ghoreyshi, A.A. Bioconversion of whey to electrical energy in a biofuel cell using Saccharomyces cerevisiae. World Appl. Sci. J. 2010, 8, 1-5.

68. Wang, C.-T.; Chen, W.-J.; Huang, R.-Y. Influence of growth curve phase on electricity performance of microbial fuel cell by Escherichia coli. Int. J. Hydrog. Energy 2010, 35, 7217-7223. [CrossRef]

69. Chaudhuri, S.K.; Lovley, D.R. Electricity generation by direct oxidation of glucose in mediatorless microbial fuel cells. Nat. Biotechnol. 2003, 21, 1229-1232. [CrossRef]

70. Mohan, Y.; Manoj Muthu Kumar, S.; Das, D. Electricity generation using microbial fuel cells. Int. J. Hydrog. Energy 2008, 33, 423-426. [CrossRef]

71. Ganguli, R.; Dunn, B.S. Kinetics of Anode Reactions for a Yeast-Catalysed Microbial Fuel Cell. Fuel Cells 2009, 9, 44-52. [CrossRef]

72. Rabaey, K.; Boon, N.; Höfte, M.; Verstraete, W. Microbial Phenazine Production Enhances Electron Transfer in Biofuel Cells. Environ. Sci. Technol. 2005, 39, 3401-3408. [CrossRef]

73. Pham, C.A.; Jung, S.J.; Phung, N.T.; Lee, J.; Chang, I.S.; Kim, B.H.; Yi, H.; Chun, J. A novel electrochemically active and Fe(III)reducing bacterium phylogenetically related to Aeromonas hydrophila, isolated from a microbial fuel cell. FEMS Microbiol. Lett. 2003, 223, 129-134. [CrossRef]

74. Kim, H.J.; Park, H.S.; Hyun, M.S.; Chang, I.S.; Kim, M.; Kim, B.H. A mediator-less microbial fuel cell using a metal reducing bacterium, Shewanella putrefaciens. Enzym. Microb. Technol. 2002, 30, 145-152. [CrossRef]

75. Yi, H.; Nevin, K.P.; Kim, B.C.; Franks, A.E.; Klimes, A.; Tender, L.M.; Lovley, D.R. Selection of a variant of Geobacter sulfurreducens with enhanced capacity for current production in microbial fuel cells. Biosens. Bioelectron. 2009, 24, 3498-3503. [CrossRef]

76. Vega, C.A.; Fernández, I. Mediating effect of ferric chelate compounds in microbial fuel cells with Lactobacillus plantarum, Streptococcus lactis, and Erwinia dissolvens. Bioelectrochemistry Bioenerg. 1987, 17, 217-222. [CrossRef]

77. Kim, B.H.; Park, H.S.; Kim, H.J.; Kim, G.T.; Chang, I.S.; Lee, J.; Phung, N.T. Enrichment of microbial community generating electricity using a fuel-cell-type electrochemical cell. Appl. Microbiol. Biotechnol. 2004, 63, 672-681. [CrossRef]

78. Lee, S.A.; Choi, Y.; Jung, S.; Kim, S. Effect of initial carbon sources on the electrochemical detection of glucose by Gluconobacter oxydans. Bioelectrochemistry 2002, 57, 173-178. [CrossRef]

79. Thygesen, A.; Poulsen, F.W.; Min, B.; Angelidaki, I.; Thomsen, A.B. The effect of different substrates and humic acid on power generation in microbial fuel cell operation. Bioresour. Technol. 2009, 100, 1186-1191. [CrossRef]

80. Rhoads, A.; Beyenal, H.; Lewandowski, Z. Microbial Fuel Cell using Anaerobic Respiration as an Anodic Reaction and Biomineralized Manganese as a Cathodic Reactant. Environ. Sci. Technol. 2005, 39, 4666-4671. [CrossRef]

81. Ringeisen, B.R.; Henderson, E.; Wu, P.K.; Pietron, J.; Ray, R.; Little, B.; Biffinger, J.C.; Jones-Meehan, J.M. High Power Density from a Miniature Microbial Fuel Cell Using Shewanella oneidensis DSP10. Environ. Sci. Technol. 2006, 40, 2629-2634. [CrossRef] [PubMed]

82. Park, D.H.; Zeikus, J.G. Improved fuel cell and electrode designs for producing electricity from microbial degradation. Biotechnol. Bioeng. 2003, 81, 348-355. [CrossRef] [PubMed]

83. Rabaey, I.; Ossieur, W.; Verhaege, M.; Verstraete, W. Continuous microbial fuel cells convert carbohydrates to electricity. Water Sci. Technol. J. Int. Assoc. Water Pollut. Res. 2005, 52, 515-523. [CrossRef]

84. Choi, Y.; Jung, E.; Park, H.; Jung, S.; Kim, S. Effect of Initial Carbon Sources on the Performance of a Microbial Fuel Cell Containing Environmental Microorganism Micrococcus luteus. Bull. Korean Chem. Soc. 2007, 28, 1591-1594. [CrossRef]

85. Garg, A.; Lam, J.S.L. Design of explicit models for estimating efficiency characteristics of microbial fuel cells. Energy 2017, 134, 136-156. [CrossRef]

86. Zinadini, S.; Zinatizadeh, A.A.; Rahimi, M.; Vatanpour, V.; Bahrami, K. Energy recovery and hygienic water production from wastewater using an innovative integrated microbial fuel cell-membrane separation process. Energy 2017, 141, 1350-1362. [CrossRef]

87. Jafary, T.; Rahimnejad, M.; Ghoreyshi, A.A.; Najafpour, G.; Hghparast, F.; Daud, W.R.W. Assessment of bioelectricity production in microbial fuel cells through series and parallel connections. Energy Convers. Manag. 2013, 75, 256-262. [CrossRef]

88. Saeed, H.M.; Husseini, G.A.; Yousef, S.; Saif, J.; Al-Asheh, S.; Abu Fara, A.; Azzam, S.; Khawaga, R.; Aidan, A. Microbial desalination cell technology: A review and a case study. Desalination 2015, 359, 1-13. [CrossRef]

89. He, L.; Du, P.; Chen, Y.; Lu, H.; Cheng, X.; Chang, B.; Wang, Z. Advances in microbial fuel cells for wastewater treatment. Renew. Sustain. Energy Rev. 2017, 71, 388-403. [CrossRef] 
90. Sadabad, H.R.; Gholikandi, G.B. Harvesting direct electricity from municipal waste-activated sludge simultaneous with its aerobic stabilization process: Investigation and optimization. J. Environ. Chem. Eng. 2017, 5, 1174-1185. [CrossRef]

91. McCarty, P.L.; Bae, J.; Kim, J. Domestic Wastewater Treatment as a Net Energy Producer-Can This be Achieved? Environ. Sci. Technol. 2011, 45, 7100-7106. [CrossRef]

92. Choudhury, P.; Uday, U.S.P.; Mahata, N.; Nath Tiwari, O.; Narayan Ray, R.; Kanti Bandyopadhyay, T.; Bhunia, B. Performance improvement of microbial fuel cells for waste water treatment along with value addition: A review on past achievements and recent perspectives. Renew. Sustain. Energy Rev. 2017, 79, 372-389. [CrossRef]

93. Liang, P.; Duan, R.; Jiang, Y.; Zhang, X.; Qiu, Y.; Huang, X. One-year operation of 1000-L modularized microbial fuel cell for municipal wastewater treatment. Water Res. 2018, 141, 1-8. [CrossRef]

94. Hiegemann, H.; Herzer, D.; Nettmann, E.; Lübken, M.; Schulte, P.; Schmelz, K.-G.; Gredigk-Hoffmann, S.; Wichern, M. An integrated 45L pilot microbial fuel cell system at a full-scale wastewater treatment plant. Bioresour. Technol. 2016, 218, 115-122. [CrossRef] [PubMed]

95. Ma, D.; Jiang, Z.-H.; Lay, C.-H.; Zhou, D. Electricity generation from swine wastewater in microbial fuel cell: Hydraulic reaction time effect. Int. J. Hydrog. Energy 2016, 41, 21820-21826. [CrossRef]

96. Vélez-Pérez, L.S.; Ramirez-Nava, J.; Hernández-Flores, G.; Talavera-Mendoza, O.; Escamilla-Alvarado, C.; Poggi-Varaldo, H.M.; Solorza-Feria, O.; López-Díaz, J.A. Industrial acid mine drainage and municipal wastewater co-treatment by dual-chamber microbial fuel cells. Int. J. Hydrog. Energy 2020, 45, 13757-13766. [CrossRef]

97. Jayashree, C.; Sweta, S.; Arulazhagan, P.; Yeom, I.T.; Iqbal, M.I.I.; Rajesh Banu, J. Electricity generation from retting wastewater consisting of recalcitrant compounds using continuous upflow microbial fuel cell. Biotechnol. Bioprocess Eng. 2015, 20, 753-759. [CrossRef]

98. Kloch, M.; Toczyłowska-Mamińska, R. Toward Optimization of Wood Industry Wastewater Treatment in Microbial Fuel CellsMixed Wastewaters Approach. Energies 2020, 13, 263. [CrossRef]

99. Park, Y.; Park, S.; Nguyen, V.K.; Yu, J.; Torres, C.I.; Rittmann, B.E.; Lee, T. Complete nitrogen removal by simultaneous nitrification and denitrification in flat-panel air-cathode microbial fuel cells treating domestic wastewater. Chem. Eng. J. 2017, 316, 673-679. [CrossRef]

100. Liu, H.; Leng, F.; Guan, Y.; Yao, Y.; Li, Y.; Xu, S. Simultaneous Pollutant Removal and Electricity Generation in a Combined ABR-MFC-MEC System Treating Fecal Wastewater. Water Air Soil Pollut. 2017, 228, 179. [CrossRef]

101. Sangcharoen, A.; Niyom, W.; Suwannasilp, B.B. A microbial fuel cell treating organic wastewater containing high sulfate under continuous operation: Performance and microbial community. Process Biochem. 2015, 50, 1648-1655. [CrossRef]

102. Mehravanfar, H.; Mahdavi, M.A.; Gheshlaghi, R. Economic optimization of stacked microbial fuel cells to maximize power generation and treatment of wastewater with minimal operating costs. Int. J. Hydrog. Energy 2019, 44, 20355-20367. [CrossRef]

103. Thung, W.-E.; Ong, S.-A.; Ho, L.-N.; Wong, Y.-S.; Oon, Y.-L.; Oon, Y.-S.; Lehl, H.K. Simultaneous Wastewater Treatment and Power Generation with Innovative Design of an Upflow Membrane-Less Microbial Fuel Cell. Water Air Soil Pollut. 2015, 226, 165. [CrossRef]

104. Tian, Y.; Li, H.; Li, L.; Su, X.; Lu, Y.; Zuo, W.; Zhang, J. In-situ integration of microbial fuel cell with hollow-fiber membrane bioreactor for wastewater treatment and membrane fouling mitigation. Biosens. Bioelectron. 2015, 64, 189-195. [CrossRef] [PubMed]

105. Mohanakrishna, G.; Abu-Reesh, I.M.; Kondaveeti, S.; Al-Raoush, R.I.; He, Z. Enhanced treatment of petroleum refinery wastewater by short-term applied voltage in single chamber microbial fuel cell. Bioresour. Technol. 2018, 253, 16-21. [CrossRef] [PubMed]

106. Aelterman, P.; Rabaey, K.; Clauwaert, P.; Verstraete, W. Microbial fuel cells for wastewater treatment. Water Sci. Technol. 2006, 54, 9-15. [CrossRef] [PubMed]

107. Ahn, Y.; Logan, B.E. Effectiveness of domestic wastewater treatment using microbial fuel cells at ambient and mesophilic temperatures. Bioresour. Technol. 2010, 101, 469-475. [CrossRef]

108. Chen, F.; Zeng, S.; Luo, Z.; Ma, J.; Zhu, Q.; Zhang, S. A novel MBBR-MFC integrated system for high-strength pulp/paper wastewater treatment and bioelectricity generation. Sep. Sci. Technol. 2020, 55, 2490-2499. [CrossRef]

109. Fang, Z.; Song, H.-l.; Cang, N.; Li, X.-N. Electricity production from Azo dye wastewater using a microbial fuel cell coupled constructed wetland operating under different operating conditions. Biosens. Bioelectron. 2015, 68, 135-141. [CrossRef]

110. Gao, C.; Liu, L.; Yang, F. Development of a novel proton exchange membrane-free integrated MFC system with electric membrane bioreactor and air contact oxidation bed for efficient and energy-saving wastewater treatment. Bioresour. Technol. 2017, 238, 472-483. [CrossRef]

111. Wu, S.; Li, H.; Zhou, X.; Liang, P.; Zhang, X.; Jiang, Y.; Huang, X. A novel pilot-scale stacked microbial fuel cell for efficient electricity generation and wastewater treatment. Water Res. 2016, 98, 396-403. [CrossRef]

112. Jayashree, C.; Tamilarasan, K.; Rajkumar, M.; Arulazhagan, P.; Yogalakshmi, K.N.; Srikanth, M.; Banu, J.R. Treatment of seafood processing wastewater using upflow microbial fuel cell for power generation and identification of bacterial community in anodic biofilm. J. Environ. Manag. 2016, 180, 351-358. [CrossRef]

113. Nguyen, H.T.H.; Kakarla, R.; Min, B. Algae cathode microbial fuel cells for electricity generation and nutrient removal from landfill leachate wastewater. Int. J. Hydrog. Energy 2017, 42, 29433-29442. [CrossRef]

114. Fazli, N.; Mutamim, N.S.A.; Jafri, N.M.A.; Ramli, N.A.M. Microbial Fuel Cell (MFC) in treating spent caustic wastewater: Varies in Hydraulic Retention Time (HRT) and Mixed Liquor Suspended Solid (MLSS). J. Environ. Chem. Eng. 2018, 6, 4339-4346. [CrossRef] 
115. Abbasi, U.; Jin, W.; Pervez, A.; Bhatti, Z.A.; Tariq, M.; Shaheen, S.; Iqbal, A.; Mahmood, Q. Anaerobic microbial fuel cell treating combined industrial wastewater: Correlation of electricity generation with pollutants. Bioresour. Technol. 2016, 200, 1-7. [CrossRef] [PubMed]

116. Cecconet, D.; Molognoni, D.; Callegari, A.; Capodaglio, A.G. Agro-food industry wastewater treatment with microbial fuel cells: Energetic recovery issues. Int. J. Hydrog. Energy 2018, 43, 500-511. [CrossRef]

117. Çetinkaya, A.Y.; Köroğlu, E.O.; Demir, N.M.; Baysoy, D.Y.; Özkaya, B.; Çakmakçı, M. Electricity production by a microbial fuel cell fueled by brewery wastewater and the factors in its membrane deterioration. Chin. J. Catal. 2015, 36, 1068-1076. [CrossRef]

118. Li, Y.; Liu, L.; Yang, F.; Ren, N. Performance of carbon fiber cathode membrane with C-Mn-Fe-O catalyst in MBR-MFC for wastewater treatment. J. Membr. Sci. 2015, 484, 27-34. [CrossRef]

119. Włodarczyk, P.P.; Włodarczyk, B. Microbial Fuel Cell with Ni-Co Cathode Powered with Yeast Wastewater. Energies 2018, 11, 3194. [CrossRef]

120. Raychaudhuri, A.; Behera, M. Comparative evaluation of methanogenesis suppression methods in microbial fuel cell during rice mill wastewater treatment. Environ. Technol. Innov. 2020, 17, 100509. [CrossRef]

121. Firdous, S.; Jin, W.; Shahid, N.; Bhatti, Z.A.; Iqbal, A.; Abbasi, U.; Mahmood, Q.; Ali, A. The performance of microbial fuel cells treating vegetable oil industrial wastewater. Environ. Technol. Innov. 2018, 10, 143-151. [CrossRef]

122. He, W.; Wallack, M.J.; Kim, K.-Y.; Zhang, X.; Yang, W.; Zhu, X.; Feng, Y.; Logan, B.E. The effect of flow modes and electrode combinations on the performance of a multiple module microbial fuel cell installed at wastewater treatment plant. Water Res. 2016, 105, 351-360. [CrossRef]

123. Ge, Z.; He, Z. Long-term performance of a $200 \mathrm{~L}$ modularized microbial fuel cell system treating municipal wastewater: Treatment, energy, and cost. Environ. Sci. Water Res. Technol. 2016, 2, 274-281. [CrossRef]

124. Kim, K.-Y.; Yang, W.; Logan, B.E. Impact of electrode configurations on retention time and domestic wastewater treatment efficiency using microbial fuel cells. Water Res. 2015, 80, 41-46. [CrossRef] [PubMed]

125. Luo, H.; Xu, G.; Lu, Y.; Liu, G.; Zhang, R.; Li, X.; Zheng, X.; Yu, M. Electricity generation in a microbial fuel cell using yogurt wastewater under alkaline conditions. RSC Adv. 2017, 7, 32826-32832. [CrossRef]

126. Marassi, R.J.; Queiroz, L.G.; Silva, D.C.V.R.; da Silva, F.T.; Silva, G.C.; de Paiva, T.C.B. Performance and toxicity assessment of an up-flow tubular microbial fuel cell during long-term operation with high-strength dairy wastewater. J. Clean. Prod. 2020, 259, 120882. [CrossRef]

127. Sawasdee, V.; Pisutpaisal, N. Simultaneous pollution treatment and electricity generation of tannery wastewater in air-cathode single chamber MFC. Int. J. Hydrog. Energy 2016, 41, 15632-15637. [CrossRef]

128. Hernández-Fernández, F.J.; Pérez de los Ríos, A.; Salar-García, M.J.; Ortiz-Martínez, V.M.; Lozano-Blanco, L.J.; Godínez, C.; Tomás-Alonso, F.; Quesada-Medina, J. Recent progress and perspectives in microbial fuel cells for bioenergy generation and wastewater treatment. Fuel Processing Technol. 2015, 138, 284-297. [CrossRef]

129. Koffi, N.D.J.; Okabe, S. Domestic wastewater treatment and energy harvesting by serpentine up-flow MFCs equipped with PVDF-based activated carbon air-cathodes and a low voltage booster. Chem. Eng. J. 2020, 380, 122443. [CrossRef]

130. Corbella, C.; Hartl, M.; Fernandez-gatell, M.; Puigagut, J. MFC-based biosensor for domestic wastewater COD assessment in constructed wetlands. Sci. Total Environ. 2019, 660, 218-226. [CrossRef]

131. Das, B.; Gaur, S.S.; Katha, A.R.; Wang, C.-T.; Katiyar, V. Crosslinked poly(vinyl alcohol) membrane as separator for domestic wastewater fed dual chambered microbial fuel cells. Int. J. Hydrog. Energy 2021, 46, 7073-7086. [CrossRef]

132. Ye, Y.; Ngo, H.H.; Guo, W.; Chang, S.W.; Nguyen, D.D.; Zhang, X.; Zhang, S.; Luo, G.; Liu, Y. Impacts of hydraulic retention time on a continuous flow mode dual-chamber microbial fuel cell for recovering nutrients from municipal wastewater. Sci. Total Environ. 2020, 734, 139220. [CrossRef]

133. Park, Y.; Nguyen, V.K.; Park, S.; Yu, J.; Lee, T. Effects of anode spacing and flow rate on energy recovery of flat-panel air-cathode microbial fuel cells using domestic wastewater. Bioresour. Technol. 2018, 258, 57-63. [CrossRef]

134. Corbella, C.; Puigagut, J. Improving domestic wastewater treatment efficiency with constructed wetland microbial fuel cells: Influence of anode material and external resistance. Sci. Total Environ. 2018, 631-632, 1406-1414. [CrossRef]

135. You, S.; Zhao, Q.; Jiang, J.; Zhang, J. Treatment of DomesticWastewaterwith Simultaneous Electricity Generation in Microbial Fuel Cell under Continuous Operation. Chem. Biochem. Eng. Q. 2006, 20, 407-412.

136. Rodrigo, M.A.; Cañizares, P.; Lobato, J.; Paz, R.; Sáez, C.; Linares, J.J. Production of electricity from the treatment of urban waste water using a microbial fuel cell. J. Power Sources 2007, 169, 198-204. [CrossRef]

137. Cheng, S.; Liu, H.; Logan, B.E. Increased Power Generation in a Continuous Flow MFC with Advective Flow through the Porous Anode and Reduced Electrode Spacing. Environ. Sci. Technol. 2006, 40, 2426-2432. [CrossRef]

138. Ahn, Y.; Hatzell, M.C.; Zhang, F.; Logan, B.E. Different electrode configurations to optimize performance of multi-electrode microbial fuel cells for generating power or treating domestic wastewater. J. Power Sources 2014, 249, 440-445. [CrossRef]

139. Puig, S.; Serra, M.; Coma, M.; Balaguer, M.D.; Colprim, J. Simultaneous domestic wastewater treatment and renewable energy production using microbial fuel cells (MFCs). Water Sci. Technol. 2011, 64, 904-909. [CrossRef]

140. Feng, Y.; He, W.; Liu, J.; Wang, X.; Qu, Y.; Ren, N. A horizontal plug flow and stackable pilot microbial fuel cell for municipal wastewater treatment. Bioresour. Technol. 2014, 156, 132-138. [CrossRef]

141. Liu, H.; Ramnarayanan, R.; Logan, B.E. Production of Electricity during Wastewater Treatment Using a Single Chamber Microbial Fuel Cell. Environ. Sci. Technol. 2004, 38, 2281-2285. [CrossRef] 
142. Min, B.; Logan, B.E. Continuous Electricity Generation from Domestic Wastewater and Organic Substrates in a Flat Plate Microbial Fuel Cell. Environ. Sci. Technol. 2004, 38, 5809-5814. [CrossRef]

143. Malaeb, L.; Katuri, K.P.; Logan, B.E.; Maab, H.; Nunes, S.P.; Saikaly, P.E. A Hybrid Microbial Fuel Cell Membrane Bioreactor with a Conductive Ultrafiltration Membrane Biocathode for Wastewater Treatment. Environ. Sci. Technol. 2013, 47, 11821-11828. [CrossRef]

144. Ortiz-Martínez, V.M.; Touati, K.; Salar-García, M.J.; Hernández-Fernández, F.J.; de los Ríos, A.P. Mixed transition metal-manganese oxides as catalysts in MFCs for bioenergy generation from industrial wastewater. Biochem. Eng. J. 2019, 151, 107310. [CrossRef]

145. Srikanth, S.; Kumar, M.; Singh, D.; Singh, M.P.; Das, B.P. Electro-biocatalytic treatment of petroleum refinery wastewater using microbial fuel cell (MFC) in continuous mode operation. Bioresour. Technol. 2016, 221, 70-77. [CrossRef]

146. Venkata Mohan, S.; Mohanakrishna, G.; Srikanth, S.; Sarma, P.N. Harnessing of bioelectricity in microbial fuel cell (MFC) employing aerated cathode through anaerobic treatment of chemical wastewater using selectively enriched hydrogen producing mixed consortia. Fuel 2008, 87, 2667-2676. [CrossRef]

147. Bolognesi, S.; Cecconet, D.; Capodaglio, A.G. 5-Agro-Industrial Wastewater Treatment in Microbial Fuel Cells. In Integrated Microbial Fuel Cells for Wastewater Treatment; Abbassi, R., Yadav, A.K., Khan, F., Garaniya, V., Eds.; Butterworth-Heinemann: Oxford, UK, 2020; pp. 93-133. [CrossRef]

148. Wang, X.; Feng, Y.J.; Lee, H. Electricity production from beer brewery wastewater using single chamber microbial fuel cell. Water Sci. Technol. 2008, 57, 1117-1121. [CrossRef]

149. Feng, Y.; Wang, X.; Logan, B.E.; Lee, H. Brewery wastewater treatment using air-cathode microbial fuel cells. Appl. Microbiol. Biotechnol. 2008, 78, 873-880. [CrossRef]

150. Kaewkannetra, P.; Chiwes, W.; Chiu, T.Y. Treatment of cassava mill wastewater and production of electricity through microbial fuel cell technology. Fuel 2011, 90, 2746-2750. [CrossRef]

151. Negassa, L.W.; Mohiuddin, M.; Tiruye, G.A. Treatment of brewery industrial wastewater and generation of sustainable bioelectricity by microbial fuel cell inoculated with locally isolated microorganisms. J. Water Process Eng. 2021, 41, 102018. [CrossRef]

152. Ha, P.T.; Lee, T.K.; Rittmann, B.E.; Park, J.; Chang, I.S. Treatment of Alcohol Distillery Wastewater Using a Bacteroidetes-Dominant Thermophilic Microbial Fuel Cell. Environ. Sci. Technol. 2012, 46, 3022-3030. [CrossRef]

153. Liu, W.; Yang, G.; Jia, H.; Wang, J. A novel UASB-MFC dual sensors system for wastewater treatment: On-line sensor recovery and electrode cleaning in the long-term operation. Chemosphere 2020, 246, 125751. [CrossRef]

154. Lu, M.; Chen, S.; Babanova, S.; Phadke, S.; Salvacion, M.; Mirhosseini, A.; Chan, S.; Carpenter, K.; Cortese, R.; Bretschger, O. Long-term performance of a 20-L continuous flow microbial fuel cell for treatment of brewery wastewater. J. Power Sources 2017, 356, 274-287. [CrossRef]

155. Koffi, N.D.J.; Okabe, S. Bioelectrochemical anoxic ammonium nitrogen removal by an MFC driven single chamber microbial electrolysis cell. Chemosphere 2021, 274, 129715. [CrossRef]

156. Tao, M.; Jing, Z.; Tao, Z.; Luo, H.; Zuo, S. Improvements of nitrogen removal and electricity generation in microbial fuel cell-constructed wetland with extra corncob for carbon-limited wastewater treatment. J. Clean. Prod. 2021, 297, 126639. [CrossRef]

157. Chatterjee, P.; Ghangrekar, M.M.; Rao, S.; Kumar, S. Biotic conversion of sulphate to sulphide and abiotic conversion of sulphide to sulphur in a microbial fuel cell using cobalt oxide octahedrons as cathode catalyst. Bioprocess Biosyst. Eng. 2017, 40, 759-768. [CrossRef]

158. Chakraborty, I.; Bhowmick, G.D.; Nath, D.; Khuman, C.N.; Dubey, B.K.; Ghangrekar, M.M. Removal of sodium dodecyl sulphate from wastewater and its effect on anodic biofilm and performance of microbial fuel cell. Int. Biodeterior. Biodegrad. 2021, 156, 105108. [CrossRef]

159. Rabaey, K.; Sompel, K.; Maignien, L.; Boon, N.; Aelterman, P.; Clauwaert, P.; Schamphelaire, L.; Pham, H.; Vermeulen, J.; Verhaege, M.; et al. Microbial Fuel Cells for Sulfide Removal. Environ. Sci. Technol. 2006, 40, 5218-5224. [CrossRef] [PubMed]

160. Lee, D.-J.; Liu, X.; Weng, H.-L. Sulfate and organic carbon removal by microbial fuel cell with sulfate-reducing bacteria and sulfide-oxidising bacteria anodic biofilm. Bioresour. Technol. 2014, 156, 14-19. [CrossRef]

161. Kaushik, A.; Singh, A. Metal removal and recovery using bioelectrochemical technology: The major determinants and opportunities for synchronic wastewater treatment and energy production. J. Environ. Manag. 2020, 270, 110826. [CrossRef]

162. Lim, S.S.; Fontmorin, J.-M.; Pham, H.T.; Milner, E.; Abdul, P.M.; Scott, K.; Head, I.; Yu, E.H. Zinc removal and recovery from industrial wastewater with a microbial fuel cell: Experimental investigation and theoretical prediction. Sci. Total Environ. 2021, 776, 145934. [CrossRef] [PubMed]

163. Wang, Q.; Lv, R.; Rene, E.R.; Qi, X.; Hao, Q.; Du, Y.; Zhao, C.; Xu, F.; Kong, Q. Characterization of microbial community and resistance gene (CzcA) shifts in up-flow constructed wetlands-microbial fuel cell treating $\mathrm{Zn}$ (II) contaminated wastewater. Bioresour. Technol. 2020, 302, 122867. [CrossRef]

164. Ali, J.; Wang, L.; Waseem, H.; Sharif, H.M.A.; Djellabi, R.; Zhang, C.; Pan, G. Bioelectrochemical recovery of silver from wastewater with sustainable power generation and its reuse for biofouling mitigation. J. Clean. Prod. 2019, 235, 1425-1437. [CrossRef] 